\title{
Anthropogenic inputs from a coastal megacity are linked to greenhouse gas concentrations in the surrounding estuary
}

\author{
Brian A. Brigham ${ }^{(0)},{ }^{1,2 *}$ Jeffrey A. Bird, ${ }^{1,2}$ Andrew R. Juhl, ${ }^{3}$ Christopher J. Zappa, ${ }^{3}$ Angel D. Montero, ${ }^{1}$ \\ Gregory D. O'Mullan ${ }^{1,2,3}$ \\ ${ }^{1}$ School of Earth and Environmental Sciences, Queens College, City University of New York, Flushing, New York \\ ${ }^{2}$ The Graduate Center of the City University of New York, New York, New York \\ ${ }^{3}$ Lamont-Doherty Earth Observatory of Columbia University, Palisades, New York
}

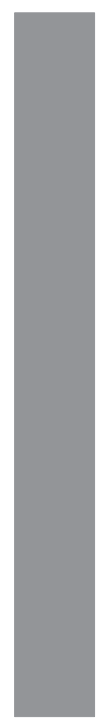

\begin{abstract}
Coastal megacities deposit significant amounts of carbon $(\mathrm{C})$, nitrogen $(\mathrm{N})$, and pollutants into surrounding waters. In urbanized estuaries, these inputs, including wastewater discharge and surface runoff, can affect biogeochemical cycles, microbial production, and greenhouse gas (GHG) efflux. To better understand estuarine GHG production and its connection to anthropogenic drivers, we quantified carbon dioxide $\left(\mathrm{CO}_{2}\right)$ and methane $\left(\mathrm{CH}_{4}\right)$ surface-water concentrations and efflux in combination with a suite of biogeochemical parameters, including anthropogenic indicators, in the Hudson River Estuary (HRE) and adjacent waters surrounding New York, NY, over a 2-yr period. The HRE was a source of both $\mathrm{CO}_{2}\left(33 \pm 3 \mathrm{mmol} \mathrm{CO}_{2} \mathrm{~m}^{-2} \mathrm{~d}^{-1}\right)$ and $\mathrm{CH}_{4}\left(177 \pm 22 \mu \mathrm{mol} \mathrm{CH}_{4} \mathrm{~m}^{-2} \mathrm{~d}^{-1}\right)$ under all measured conditions. Surface-water salinity, oxygen saturation, fecal indicator bacteria, nitrate concentrations, and temperature best explained the variance in $\mathrm{CO}_{2}$ and $\mathrm{CH}_{4}$ concentrations in multiple regression analyses, producing robust predictive power for both GHGs. Our multifaceted data set demonstrated that $\mathrm{CH}_{4}$ and $\mathrm{CO}_{2}$ surface concentrations are explained in part by enterococci concentrations, a widely used wastewater biological indicator, explicitly linking wastewater inputs to GHG surface concentrations in the HRE. The greatest $\mathrm{CO}_{2}$ and $\mathrm{CH}_{4}$ surface-water concentrations were found in urban tributaries and embayments, primary wastewater delivery areas throughout the HRE. Estuarine tributaries and embayments have historically received less research attention than midchannel sites, but since these shallow sites may contribute to increased GHG efflux in anthropogenically impacted estuaries, further study is warranted.
\end{abstract}

Estuaries are among the most biologically productive ecosystems in the world, serving as critical intermediaries between terrestrial and aquatic ecosystems and are important zones of biogeochemical activity (Bianchi 2007). While estuaries cover $0.2 \%$ of the Earth's surface, they are estimated to have a disproportionally large impact on global greenhouse gas (GHG) production, including approximately $0.5 \%$ of methane $\left(\mathrm{CH}_{4}\right)$, $2-4 \%$ of nitrous oxide $\left(\mathrm{N}_{2} \mathrm{O}\right)$, and $2-5 \%$ of carbon dioxide $\left(\mathrm{CO}_{2}\right)$ emissions (Borges and Abril 2011; Ciais et al. 2013; Murray et al. 2015). Despite its potential impact on climate, research on estuarine GHG efflux is sparse, resulting in poorly constrained emission estimates (Bange 2006). GHG fluxes are particularly unconstrained for estuaries that are urbanized, or otherwise anthropogenically impacted in ways that could enhance GHG production, such as through agricultural runoff,

*Correspondence: bbrigham@gradcenter.cuny.edu

Additional Supporting Information may be found in the online version of this article. wastewater discharges, or land-use changes (Frankignoulle et al. 1998; Doney 2010; Regnier et al. 2013).

Estuarine $\mathrm{CO}_{2}$ surface concentrations and efflux into the atmosphere are generally greatest "upstream" in proximity to tributaries that serve as carbon (C) and nitrogen (N) sources (Chen et al. 2012). Substantial seasonal variability, linked to the strong correlation between temperature and net heterotrophy, has also been observed across estuaries worldwide (Frankignoulle et al. 1998). Surface concentrations have been shown to be positively correlated to temperature, dissolved organic carbon (DOC), and chlorophyll $a$ ( $\mathrm{Chl} a$ ) concentrations, and negatively correlated with river flow and oxygen saturation (Borges and Abril 2011). In addition to typical upstream/downstream trends, natural or anthropogenic inputs of labile $\mathrm{C}$ and other nutrients (e.g., sources of $\mathrm{N}$ and phosphorus) can enhance microbial activity, stimulating $\mathrm{CO}_{2}$ production via direct and indirect pathways (Turner and Rabalais 1994).

Like $\mathrm{CO}_{2}, \mathrm{CH}_{4}$ concentrations are often greater in the "upstream" portion of estuaries (Middelburg et al. 2002). $\mathrm{CH}_{4}$ concentrations typically decrease with increasing estuarine 
salinity because sulfate carried with seawater increases competition between sulfate reducers and methanogens, limiting $\mathrm{CH}_{4}$ production in more saline waters (Bartlett et al. 1987; Capone and Kiene 1988). However, rivers and estuaries with large urban and/or agricultural influences including the Scheldt, Pearl, Seine, and Hudson River estuaries/watersheds demonstrated supersaturated $\mathrm{CO}_{2}$ and $\mathrm{CH}_{4}$ concentrations in downstream regions (Kempe 1984; Raymond et al. 1997; Frankignoulle et al. 1998; Abril et al. 2000; Middelburg et al. 2002; Chen et al. 2013; Regnier et al. 2013; Marescaux et al. 2018), suggesting that anthropogenic inputs can alter upstream/downstream trends. Nevertheless, data explicitly linking anthropogenic inputs to enhanced estuarine GHG efflux are lacking (Burgos et al. 2015).

In this study, $\mathrm{CO}_{2}$ and $\mathrm{CH}_{4}$ surface concentrations and efflux were quantified for the Hudson River Estuary (HRE) at both midchannel and tributary sites. The HRE is a highly urbanized system that supports more than 12 million people and experiences among the highest external anthropogenic DOC and dissolved inorganic N (DIN) inputs in the world (Howarth et al. 2006). Including tributaries in this study is significant because tributary mixing zones typically receive the largest natural and anthropogenic (specifically wastewater) DOC and DIN inputs. Most prior studies have focused on midchannel measurements, omitting potential hotspots of GHG production and associated anthropogenic inputs. In addition, the GHG measurements in this study were paired with a suite of anthropogenic wastewater indicators, providing one of the most comprehensive examinations of the relationship between GHG dynamics and wastewater inputs in urbanized estuaries.

Comparing urbanized regions in the brackish (New York City [NYC]) and fresh (Albany) sections of the estuary with less developed regions allowed us to separate anthropogenic impacts from salinity-dependent patterns of GHG surface concentrations and efflux. We hypothesized first that $\mathrm{CO}_{2}$ and $\mathrm{CH}_{4}$ surface concentrations would be greatest near urban centers (Albany and NYC) compared with less-developed areas, regardless of salinity $(\mathrm{H} 1)$. Second, the greatest $\mathrm{CO}_{2}$ and $\mathrm{CH}_{4}$ surface concentrations would be found in urban and upriver tributaries ( $\mathrm{H} 2)$. Finally, $\mathrm{CO}_{2}$ and $\mathrm{CH}_{4}$ surface concentrations in the HRE would positively correlate with indicators of anthropogenic loading, such as DOC, nitrate $\left(\mathrm{NO}_{3}^{-}\right)$, and fecal indicator bacteria concentrations (H3).

\section{Materials and methods}

\section{Site information}

The HRE is a partially mixed estuary with a moderate salinity gradient and vertical stratification (Geyer and Chant 2006) (Fig. 1). It is tidal between the Battery (river kilometer [RK] 0 at the southern tip of Manhattan) and the Federal Dam at Troy, NY (RK 245). The salt front and an associated estuarine turbidity maximum are typically located between Haverstraw Bay (RK 60) and West Point, NY (RK 85), largely dependent on river flow (Geyer and Chant 2006). A stronger turbidity maximum is

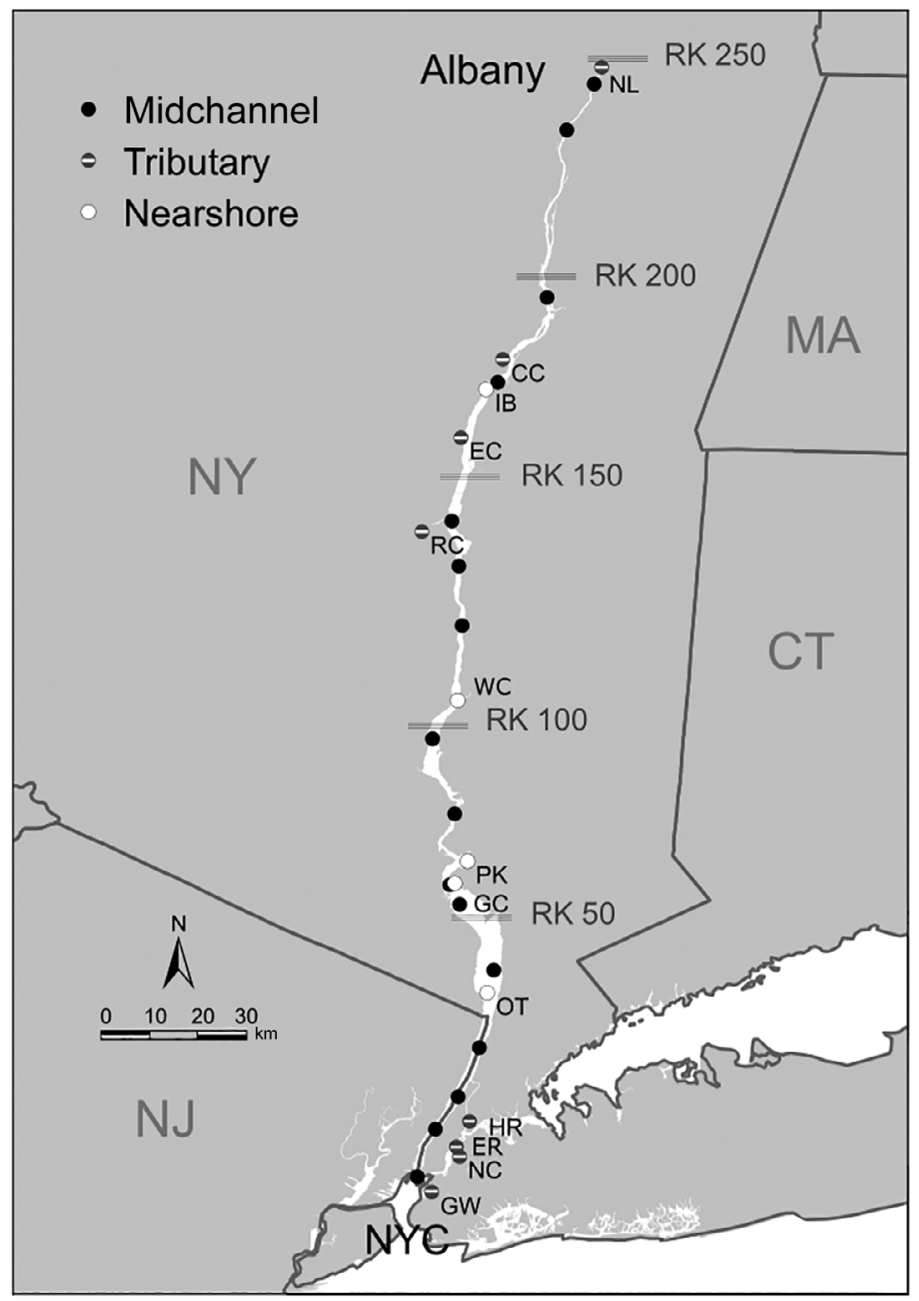

Fig. 1. Map detailing the tidal HRE and the location of each midchannel, $(n=17)$ tributary $(n=7)$, and nearshore sites $(n=5)$ in relation to New York City (NYC) and Albany. NYC is located at the ocean terminus and Albany is located at the upriver terminus of the tidal HRE. For this study, the lower estuary will refer to saline and brackish waters between the Battery (RK 0) and West Point, NY (RK 85) and the upper estuary will refer to tidal freshwaters between West Point, NY, and Troy, NY, as defined in previous HRE publications (Howarth et al. 2006; Levinton and Waldman 2006). Tributaries listed south to north are Gowanus Canal (GW), Newtown Creek (NC), East River (ER), Harlem River (HR), Rondout Creek (RC), Esopous Creek (EC), Catskill Creek (CC), Orangetown Outfall (OT), Peekskill (PK), Wappinger Creek (WC), and Inbocht Bay (IB). NY represents New York state, NJ represents New Jersey, CT represents Connecticut, and MA represents Massachusetts.

located closer to the mouth of the estuary in the zone of greatest salinity stratification (between $79^{\text {th }}$ Street [RK 11] and the George Washington Bridge [RK 19], Bokuniewicz 2006).

The HRE has overlaying salinity and "urban" gradients with the most densely populated areas located at both the southern brackish (NYC) and northern fresh (Albany) termini. External inputs of DOC and DIN are split between upriver tributaries (42\%) and wastewater effluent (58\%) (Howarth et al. 2006). In NYC alone, recent measurements show an average of $4.9 \times 10^{6} \mathrm{~m}^{3} \mathrm{~d}^{-1}$ of treated, and $1.9 \times 10^{5} \mathrm{~m}^{3} \mathrm{~d}^{-1}$ of untreated 
Table 1. Sampling dates and conditions.

\begin{tabular}{lccccc}
\hline No. & Year & Month & Day & Sites visited & River flow $\left(\mathbf{m}^{\mathbf{3}} \mathbf{d}^{-\mathbf{1}}\right)^{*}$ \\
\hline 1 & 2013 & Jul & $17-21$ & All & $3.0 \mathrm{E}+07$ \\
2 & 2013 & Aug & $14-15$ & Half & $3.3 \mathrm{E}+07$ \\
3 & 2013 & Sep & $18-21$ & All & $1.3 \mathrm{E}+07$ \\
4 & 2013 & Oct & $16-17$ & Half & All \\
5 & 2014 & May & $12-15$ & All & $4.6 \mathrm{E}+07$ \\
6 & 2014 & Jun & $12-15$ & All & $7.0 \mathrm{E}+07$ \\
7 & 2014 & Jul & $07-10$ & Half & $3.5 \mathrm{E}+07$ \\
8 & 2014 & Aug & $11-12$ & All & $1.4 \mathrm{E}+07$ \\
9 & 2014 & Sep & $07-10$ & All & $1.3 \mathrm{E}+07$ \\
10 & 2014 & Oct & $12-16$ & & $1.5 \mathrm{E}+07$ \\
\hline
\end{tabular}

"All" indicates that we sampled each site.

"Half" indicates we sampled the brackish river (RK 0-69).

*River flow data procured from United States Geological Survey (USGS) Green Island station data.

wastewater discharge (City of New York Department of Environmental Protection [NYCDEP], accessed April 2018, http:// www.nyc.gov/html/dep/pdf/hwqs2012.pdf) (Supporting Information Table S1). In the saline portion of the HRE near NYC, wastewater entering the estuary from submerged sewage outfalls accounts for large external DOC (ca. $94 \mathrm{~g} \mathrm{C} \mathrm{m}^{-2} \mathrm{yr}^{-1}$ ) and DIN (ca. $374 \mathrm{~g} \mathrm{~N} \mathrm{~m}^{-2} \mathrm{yr}^{-1}$ ) inputs. The $\mathrm{N}$ loading also enhances phytoplankton growth and turnover, ultimately leading to total DOC inputs estimated at ca. $944 \mathrm{~g} \mathrm{C} \mathrm{m}^{-2} \mathrm{yr}^{-1}$ (Howarth et al. 2006). Sewage-derived DOC and DIN originating near NYC can likely be transported upriver by tidal action as far as the salt front (Brosnan et al. 2006) (Supporting Information Table S1).

In contrast, the majority of external DOC and DIN input to the upper fresh HRE is sourced from tributaries, not wastewater (Howarth et al. 1996). These tributaries include the upper Hudson and Mohawk Rivers (RK > 250), which account for $80 \%$ of freshwater input to the HRE (flow rate $2.9-4.8 \mathrm{~L} \mathrm{~min}^{-1}$ ), with the balance coming from smaller tributaries (Cooper et al. 1988). Wastewater inputs from this region are dominated by Albany $\left(6.3 \times 10^{5} \mathrm{~m}^{3} \mathrm{~d}^{-1}\right)$ at the freshwater terminus of the HRE but are also sourced from the Kingston $\left(1.8 \times 10^{4} \mathrm{~m}^{3} \mathrm{~d}^{-1}\right)$, Poughkeepsie $\left(2.3 \times 10^{4} \mathrm{~m}^{3} \mathrm{~d}^{-1}\right)$, and Beacon/Newburgh $\left(3.9 \times 10^{4} \mathrm{~m}^{3} \mathrm{~d}^{-1}\right)$ metro areas (United States Environment Protection Agency [USEPA], accessed April 2018, https://echo.epa. gov). However, given that the cumulative discharge of these smaller metro areas is approximately $14 \%$ of the NYC discharge, the relative importance of sewage as a source of DOC and DIN is lower in the upper, freshwater portion of the HRE.

\section{Sampling}

In total, 17 midchannel sites were sampled between the Battery (RK 0) and the Troy Bridge in Albany (RK 244), an average of approximately $15 \mathrm{~km}$ between stations, in May-October of 2013 and 2014 (Table 1). In addition, nine tributary and nearshore sites in the freshwater region upstream and five sites in urban tributaries located near NYC were sampled
(Supporting Information Tables S2, S3). The majority of measurements were collected from the Riverkeeper patrol boat, R. Ian Fletcher, in coordination with their monthly water quality survey. Surface water was pumped from the side of the boat at $\sim 2 \mathrm{~L} \mathrm{~min}^{-1}$ to a Hydrolab DS5X sonde (Hach; Boulder, CO, U.S.A.) and Mini-pro $\mathrm{CO}_{2}$ (Pro-Oceanus; Halifax, NS, Canada) probe. The Hydrolab sonde measured conductivity, turbidity, temperature, oxygen saturation, and chlorophyll fluorescence while on station (typically 8-10 min per site). The Mini-pro $\mathrm{CO}_{2}$ probe directly measured the partial pressure of $\mathrm{CO}_{2}$ or $p \mathrm{CO}_{2}$ values every $2 \mathrm{~s}$ equating to $>240$ measurements for each station. Exploratory bottom water samples were collected to ascertain potential sources of $\mathrm{CH}_{4}$ and $p \mathrm{CO}_{2}$ but were not used for statistical analyses because of a lack of replication $(n=1)$.

Additional surface samples were collected to quantify $\mathrm{CH}_{4}$ (250 mL, $n=3-5$ per site, per cruise), fecal indicator bacteria (enterococci, $100 \mathrm{~mL}, n=1$ per site, per cruise), as well as DOC and DIN (50 mL, $n=1$ per site, per cruise) surface concentrations. Samples for $\mathrm{CH}_{4}$ and enterococci were processed immediately on board, while samples for DOC and DIN analyses were placed immediately on ice and then kept at $-20^{\circ} \mathrm{C}$ (within $24 \mathrm{~h}$ ) until analyses were completed. Actual (not the partial pressure) $\mathrm{CH}_{4}$ surface concentrations were determined using the extraction method detailed by McAuliffe (1971) that in brief, entails extracting $\mathrm{CH}_{4}$ from water samples $(30 \mathrm{~mL})$ in syringes flushed and filled with $\mathrm{N}_{2}$ gas $(30 \mathrm{~mL})$ followed by transfer and storage in $12 \mathrm{~mL}$ pre-evacuated exetainers (Labco; Lampeter, UK). Within $96 \mathrm{~h}$, all gas samples were injected (via sample loop) onto a 3-m long molecular sieve column (Restek; Bellefonte, PA, U.S.A.) installed in a Hewlett-Packard 5890 Series plus II Gas Chromatograph (HP; Brielle, NJ, U.S.A.) equipped with a flame ionization detector for analyses. Fecal indicator bacteria, enterococci, were enumerated from surface samples within $6 \mathrm{~h}$ of collection following USEPA guidelines as described in Young et al. (2013). DIN concentrations defined as $\mathrm{NO}_{3}^{-}$plus ammonium $\left(\mathrm{NH}_{4}^{+}\right)$of sample surface waters were determined using standard colorimetric assays (Weatherburn 1967; Doane and 
Horwáth 2003) performed with a Synergy H1 plate reader (Biotek, Winoski, VT, U.S.A.). Nonpurgeable organic C (referred to hereafter as DOC, a technical near equivalent and more common usage) was determined by the hightemperature combustion method (American Public Health Association 2005) with a TOC-V CSH analyzer (Shimadzu, Kyoto, Japan).

\section{Efflux calculations}

Efflux $(F)$ was estimated using a simple model that assumes Fickian diffusion shown in Eq. 1:

$$
F=k \Delta C
$$

where $k$ is the gas transfer velocity and $\Delta C$ is the gas concentration difference across the air-water interface (Liss and Slater 1974). $\mathrm{CH}_{4}$ and $p \mathrm{CO}_{2}$ were measured in surface waters to determine their difference across the water-air interface. Henry's law solubility was utilized to convert $p \mathrm{CO}_{2}$ to the concentration at the water surface in equilibrium with the air (Weiss 1974). $k$ is dependent upon the specific gas of interest and on wind speed, often as an exponential or squared function in most models. If the $k$ was known for a particular gas, the $k$ for other gases (in this case $\mathrm{CH}_{4}$ and $\mathrm{CO}_{2}$ ) can be calculated by the ratio of their respective Schmidt numbers (Sc). This number is the kinematic viscosity of water divided by the diffusion constant for the gas(es) of interest, obtained from Wanninkhof (1992) and adjusted according to each sample's salinity and temperature. The models used to calculate $k$ were taken from two different publications allowing efflux estimates to be evaluated in the context of physical conditions specific to the HRE (Raymond and Cole 2001; Ho et al. 2011). Models representing open ocean conditions (Wanninkhof 1992; Nightingale et al. 2000; Ho et al. 2006) which may not reflect actual conditions in the HRE were included to allow comparisons to other estuarine studies, which commonly use these models. The models are listed in Eqs. 2-6, where $u_{10}$ and Sc represent wind speed adjusted to $10 \mathrm{~m}$ height and the Schmidt number calculated from salinity and temperature from each sampling, respectively.

$$
\begin{gathered}
\text { Ho et al. }(2006), \quad k_{\mathrm{sc}}=0.266 u_{10}^{2}(\mathrm{Sc} / 600)^{-1 / 2} \\
\text { Ho et al. }(2011), \quad k_{\mathrm{sc}}=\left[0.06+0.266 u_{10}^{2}\right](\mathrm{Sc} / 600)^{-1 / 2} \\
\text { Raymond and Cole }(2001), \quad k_{\mathrm{sc}}=1.58 e^{0.3 u_{10}}(\mathrm{Sc} / 600)^{-1 / 2} \\
\text { Nightingale et al. }(2000), \quad k_{\mathrm{sc}}=\left[0.222 u_{10}^{2}+0.333 u_{10}\right](\mathrm{Sc} / 600)^{-1 / 2}
\end{gathered}
$$

$$
\text { Wanninkhof }(1992), \quad k_{\mathrm{sc}}=0.31 u_{10}^{2}(\mathrm{Sc} / 660)^{-1 / 2}
$$

Efflux calculations were determined for midchannel sites only, which are located in the main shipping channel, and have average water depths of approximately $15 \pm 5 \mathrm{~m}$. At shallower depths, bottom shear, tides, fetch, and stratification, not measured in this study, would be as important as wind speed for estimating efflux (Zappa et al. 2007). Therefore, tributaries and nearshore sites were excluded from efflux calculations. Wind speed data (scalar) were collected from a series of meteorological towers located in close proximity to Kingston, Beacon, and Scarborough, NY, provided by WeatherFlow (Scotts Valley, CA, U.S.A.).

\section{Analyses}

Potential connections between GHG efflux and urbanization were investigated in multiple regression analyses relating surface $\mathrm{CO}_{2}$ and $\mathrm{CH}_{4}$ concentrations from midchannel sites to parameters measured in situ at the time of sample collection (i.e., conductivity, turbidity, etc.) and to other available contextual data including rainfall, river flow (United States Geological Survey [USGS], accessed April 2018, https://waterdata. usgs.gov/nwis/uv?site_no=01358000), historic enterococci geometric means per station (Riverkeeper, accessed April 2018, https://www.riverkeeper.org/water-quality/hudson-river/), and modeled wastewater input (NYCDEP, accessed April 2018, http://www.nyc.gov/html/dep/pdf/green_infrastructure/ gi-performance-metrics-report-2016.pdf). All data were transformed (square root) to ensure assumptions necessary for ANOVA, regression analysis, and canonical correlation analysis (CCA) tests were met. For ANOVA analyses, data were binned into four regions: brackish urban (NYC; RK 0-19), brackish sub/urban rural (RK 30-69), fresh sub/urban (RK 84-182), and fresh urban (Albany; RK 197-244) determined by salinity and wastewater discharge (Fig. 2, Supporting Information Figure S1) to reflect a priori expectations in GHG surface concentrations. Subsequently, $\mathrm{CH}_{4}$ and $\mathrm{CO}_{2}$ concentrations from tributary sites were compared to midchannel sites (using Wilcoxon signedrank tests) to assess whether tributaries were sources of elevated $\mathrm{CH}_{4}$ and $\mathrm{CO}_{2}$ values observed in urban areas. For regression analyses, data were binned only by salinity, with separate analyses for the brackish (Battery [RK 0] to Peekskill [RK 69]) and fresh (West Point [RK 84] to Troy [RK 244]) regions because exploratory analyses demonstrated that some underlying relationships were different in these two regions. All measured parameters and collected data were tested in multiple linear regression models (with $\mathrm{CH}_{4}$ and $\mathrm{CO}_{2}$ surface values separately) using both the Bayesian and Akaike information criteria to choose significant parameters for the final multiple linear regression models. All ANOVA, regression analyses, and Wilcoxon tests were conducted with SYSTAT (v.13.0, Systat Software, San Jose, CA, U.S.A.) while the CCA ordination was conducted with PCORD (v. 6.0).

\section{Results}

\section{$\mathrm{CH}_{4}$ and $\mathrm{CO}_{2}$ surface values were elevated in urban areas}

Surface $\mathrm{CH}_{4}$ concentrations from midchannel sites in the HRE ranged 65-660 $\mathrm{nmol} \mathrm{L}^{-1}$ during the sampling period (Fig. 3a). These concentrations were greatest in both the lower 


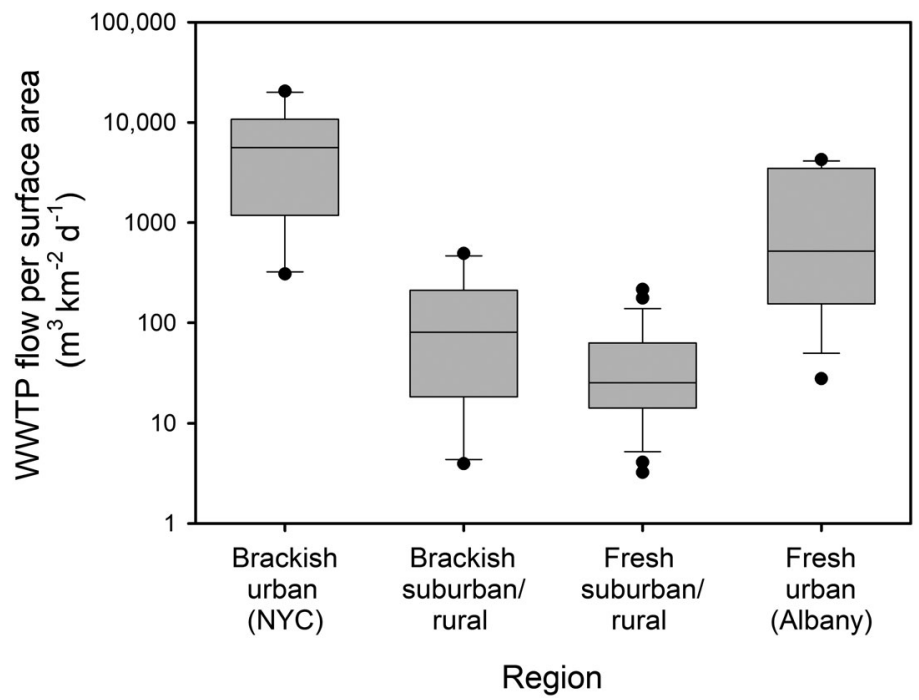

Fig. 2. Distribution of wastewater treatment plant flow (WWTP) normalized to river surface area of each region of the HRE individually including; brackish urban (NYC; RK 0-19), brackish suburban/rural (RK 30-69), fresh suburban/rural (RK 84-182), and fresh urban (Albany; RK 197-244). Daily WWTP flows are estimated from data available from https://echo.epa.gov. Distribution of WWTP flow normalized to river volume demonstrated in Supporting Information Figure S2.

and upper termini of the HRE, corresponding to urbanized areas that receive high anthropogenic $\mathrm{C}$ and $\mathrm{N}$ inputs. Lowest $\mathrm{CH}_{4}$ concentrations were found in the midestuary (RK 20-197) suburban/rural regions, regardless of salinity. These data produced a U-shaped pattern of $\mathrm{CH}_{4}$ surface concentrations along the length of the estuary. A blocked ANOVA with region and month as grouping variables demonstrated significant differences in $\mathrm{CH}_{4}$ surface concentrations among regions $\left(F_{3,125}=12\right.$, $p<0.001)$, but not sampling months $\left(F_{9,125}=2, p=0.097\right)$ (Supporting Information Tables S4a, S4b). Brackish urban tributaries had enhanced $\mathrm{CH}_{4}$ surface concentrations ranging from 197 to $5672 \mathrm{nmol} \mathrm{L}^{-1}$ (Fig. 4a). Average $\mathrm{CH}_{4}$ surface concentrations in brackish urban tributaries were significantly $\left(U_{1}=248\right.$, $p<0.001)$ greater $(3.1 \times)$ than in neighboring midchannel sites (Supporting Information Table S5). Similarly, enhanced (3.0x) $\mathrm{CH}_{4}$ surface concentrations were also found in upriver fresh suburban/rural tributaries compared to nearby midchannel sites (Fig. 4b), although the magnitude of $\mathrm{CH}_{4}$ concentrations in both these tributaries and bordering midchannel sites were lower (1.5 $\times$ ) than in the NYC region.

The pattern of surface $p \mathrm{CO}_{2}$ from midchannel sites (spanning 460-1953 $\mu \mathrm{atm}$ ) differed from those observed for $\mathrm{CH}_{4}$ (Fig. 3b). Greatest $p \mathrm{CO}_{2}$ values were observed in the lower and midestuary with the brackish urban, brackish suburban/rural, and fresh suburban/rural having significantly $\left(F_{3,83}=9, p<0.001\right)$ higher concentrations than those in the fresh urban region (Supporting Information Tables S4a, S4b). Additionally, sampling month, a factor in the ANOVA analysis, was significant $\left(F_{5,83}=9\right.$, $p<0.001)$ with the greatest average $p \mathrm{CO}_{2}$ surface values measured in August $(1694 \pm 28 \mu \mathrm{atm})$ and the lowest in May
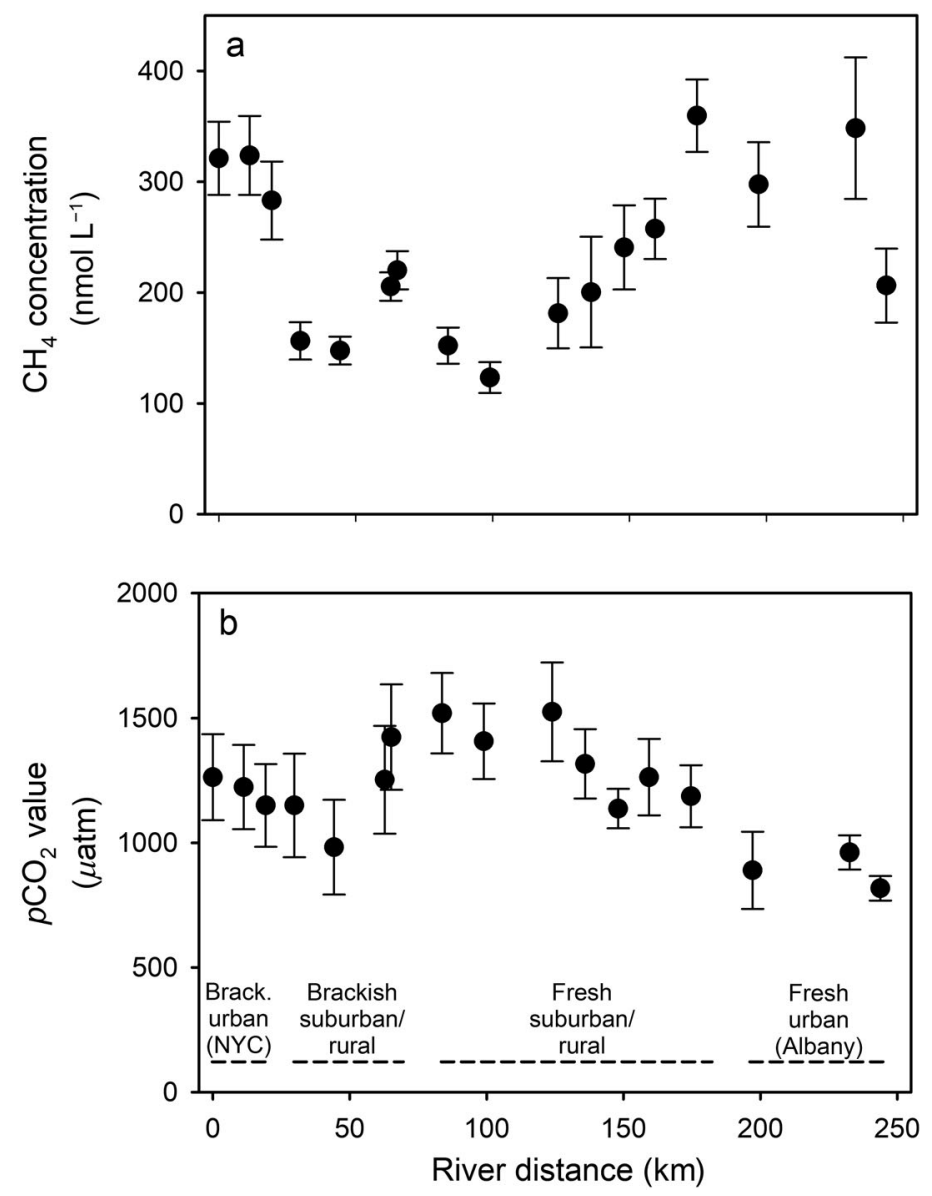

Fig. 3. Graphs illustrates average (a) methane $\left(\mathrm{CH}_{4}\right)$ and (b) carbon dioxide $\left(\mathrm{CO}_{2}\right)$ surface values measured at midchannel sites throughout the tidal HRE. $\mathrm{CH}_{4}$ concentrations were significantly greater at both the fresh and brackish terminus of the estuary. Error bars are standard error of the mean. For analysis, the HRE was divided into four regions represented by the dash bar parallel to the $\mathrm{x}$-axis including brackish urban (NYC; RK 0-19), brackish suburban/rural (RK 30-69), fresh suburban/rural (RK 84-182), and fresh urban (Albany; RK 197-244).

(749 $\pm 31 \mu \mathrm{atm})$. Surface $p \mathrm{CO}_{2}$ values were significantly enhanced $(\sim 1.6 \times)$ in brackish urban tributaries compared to neighboring midchannel sites (Fig. 4b; Supporting Information Table S5), though the enhancement of $p \mathrm{CO}_{2}$ in urban tributaries was lower than for $\mathrm{CH}_{4}$.

Overall, surface values of $\mathrm{CH}_{4}$ and $\mathrm{CO}_{2}$ in the HRE exceeded atmospheric saturation concentrations $(2 \mu \mathrm{atm}$ and $400 \mu \mathrm{atm}$, respectively) for almost all measurements (i.e., $>99 \%$ of sites and sampling dates). $\mathrm{CH}_{4}$ and $p \mathrm{CO}_{2}$ values from midchannel sites in the HRE were consistent with the range of values reported for macrotidal estuaries worldwide (Tables 2-3). Furthermore, $\mathrm{CH}_{4}$ concentrations for tributary sites were within the top $25 \%$ percentile of these values. Measurements of $\mathrm{CH}_{4}$ and $p \mathrm{CO}_{2}$ from bottom waters were $10-30 \%$ greater than surface values, suggesting that bottom sediments were the likely source of both gases with little in situ loss in the water column. Last, DOC and $\mathrm{NO}_{3}^{-}$concentrations $\left(\mathrm{NH}_{4}^{+}\right.$concentrations were below the 

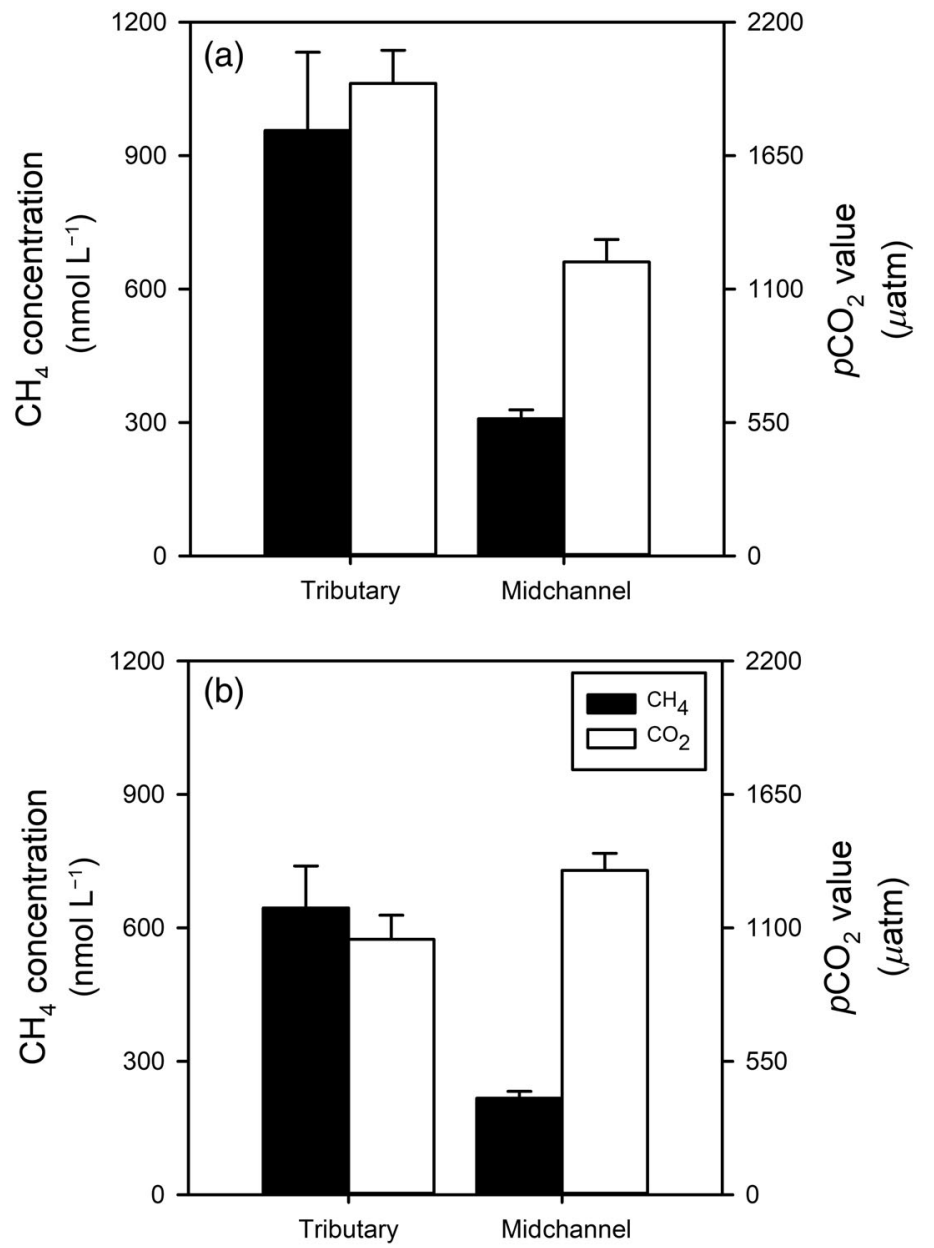

Fig. 4. Graphs illustrates comparison of average midchannel to tributary methane $\left(\mathrm{CH}_{4}\right)$ and carbon dioxide $\left(\mathrm{CO}_{2}\right)$ surface values for the (a) brackish urban region surrounding NYC between RK 0 and RK 19 and (b) the fresh suburban/rural region located between RK 84 and RK 175 . In both regions, at least three midchannel and tributaries sites were utilized to calculate average concentrations. Brackish suburban/rural (RK 30-69) and fresh urban (RK 197-244) regions lack a substantial number $(n \leq 1)$ of tributaries to make similar comparisons. Error bars are standard error of the mean.

limit of detection of $0.3 \mathrm{mg} \mathrm{L}^{-1}$ ) were not significantly different between midchannel and tributary sites. Average midchannel concentrations for DOC and $\mathrm{NO}_{3}^{-}$were $3.1 \pm 0.6 \mathrm{mg} \mathrm{L}^{-1}$ and $0.4 \pm 0.2 \mathrm{mg} \mathrm{L}^{-1}$, respectively.

\section{Biogeochemical parameters largely explain variance in} $p \mathrm{CO}_{2}$ and $\mathrm{CH}_{4}$ surface values

Biogeochemical parameters quantified in this study were used to explain the variance in midchannel $\mathrm{CH}_{4}$ and $p \mathrm{CO}_{2}$ surface values in multiple regression models. Regional summaries of all measured midchannel and tributary parameters are shown in Tables $4-5$, respectively. In the brackish region, midchannel surface $\mathrm{CH}_{4}$ concentrations were significantly explained $\left(r^{2}=0.41, F_{5,63}=9, p<0.001\right)$ by variation (listed in order of importance) in salinity ( $t=5.6)$, Chl $a$ fluorescence $(t=-3.3)$, enterococci concentrations $(t=2.6)$, oxygen saturation $(t=2.5)$, and temperature $(t=2.5)$. However, the trend was not significant $\left(r^{2}=0.061\right)$ in the fresh region (Supporting Information Table S6). The variance in midchannel $p \mathrm{CO}_{2}$ values was explained $\left(r^{2}=0.85, F_{4,37}=52\right.$, $p<0.001)$, in order of importance, by oxygen saturation $(t=-9.1)$, temperature $(t=4.5), \mathrm{NO}_{3}^{-}$concentration $(t=2.4)$, and enterococci concentration $(t=2.2)$ in the brackish region of the HRE. In the fresh region, variances in $p \mathrm{CO}_{2}$ values were significantly explained $\left(r^{2}=0.89, F_{5,39}=63, p<0.001\right)$ by similar factors in addition to river discharge $(t=2.7)$. CCA tests using all midchannel parameters demonstrated that location (sampling sites) from each designated region grouped together in multivariate space whether they were analyzed in brackish or fresh regions for both $\mathrm{CH}_{4}$ (Fig. 5a,b) and $p \mathrm{CO}_{2}$ (Fig. 5c,d) values or over the entire estuary (data not shown).

\section{$\mathrm{CH}_{4}$ and $\mathrm{CO}_{2}$ efflux}

The range of average $\mathrm{CH}_{4}$ efflux for sites in the HRE was 61-354 $\mu \mathrm{mol} \mathrm{CH}_{4} \quad \mathrm{~m}^{-2} \quad \mathrm{~d}^{-1}$. The brackish urban region $\left(292 \pm 85 \mu \mathrm{mol} \mathrm{CH}_{4} \mathrm{~m}^{-2} \mathrm{~d}^{-1}\right.$ ) had the greatest average efflux followed by fresh suburban/rural $\left(179 \pm 33 \mu \mathrm{mol} \mathrm{CH}_{4} \mathrm{~m}^{-2} \mathrm{~d}^{-1}\right)$, urban fresh $\left(123 \pm 24 \mu \mathrm{mol} \mathrm{CH}_{4} \mathrm{~m}^{-2} \mathrm{~d}^{-1}\right)$, and brackish suburban/rural $\left(122 \pm 15 \mu \mathrm{mol} \mathrm{CH}_{4} \mathrm{~m}^{-2} \mathrm{~d}^{-1}\right)$ regions (Table 6). This pattern differed from $\mathrm{CH}_{4}$ surface concentrations due primarily to the different wind speeds characteristic of each region. Average $\mathrm{CO}_{2}$ efflux ranged 9-69 $\mathrm{mmol} \mathrm{CO}_{2} \mathrm{~m}^{-2} \mathrm{~d}^{-1}$. Similar $\mathrm{CO}_{2}$ efflux values were quantified in the brackish urban $(29 \pm 5$ $\left.\mathrm{mmol} \mathrm{CO} 2 \mathrm{~m}^{-2} \mathrm{~d}^{-1}\right)$, brackish suburban/urban (35 \pm 6 mmol CO$\left.~_{2} \mathrm{~m}^{-2} \mathrm{~d}^{-1}\right)$, and fresh suburban/rural $(41 \pm 6 \mathrm{mmol}$ $\mathrm{CO}_{2} \mathrm{~m}^{-2} \mathrm{~d}^{-1}$ ), with the lowest values observed in the fresh urban (13 $\left.\pm 2 \mathrm{mmol} \mathrm{CO}_{2} \mathrm{~m}^{-2} \mathrm{~d}^{-1}\right)$ regions of the HRE (Table 6). All $\mathrm{CH}_{4}$ and $\mathrm{CO}_{2}$ efflux values are detailed in Supporting Information Tables S8, S9.

\section{Discussion}

$\mathrm{CH}_{4}$ surface concentrations were highest in urban areas

Consistent with $\mathrm{H} 1$, significantly greater midchannel $\mathrm{CH}_{4}$ concentrations were observed in close proximity to both NYC (brackish urban) and Albany (fresh urban) at opposite ends of the tidal HRE compared with the less developed midestuary (brackish and fresh suburban/rural), resulting in a U-shaped concentration pattern for $\mathrm{CH}_{4}$. In contrast, midchannel $p \mathrm{CO}_{2}$ surface values were similar throughout the HRE with no significant differences among average values across the brackish urban, brackish suburban/rural, and fresh suburban/rural regions. Elevated surface concentrations of $\mathrm{CH}_{4}(3.1 \times)$ and $\mathrm{CO}_{2}(1.6 \times)$ in urban tributaries, compared with adjacent midchannel sites, supported $\mathrm{H} 2$. The higher surface values of $\mathrm{CH}_{4}$ and $\mathrm{CO}_{2}$ quantified in urban tributaries and tidal straits, each containing up to 50 sewage delivery sites (NYCDEP 2009), are likely the result of direct inputs of GHGs transported along with sewage discharges, which have been quantified directly in streams and inland waters (Alshboul et al. 2016; Martinez- 
Table 2. $\mathrm{CH}_{4}$ surface concentrations and efflux ranges reported in estuaries.

\begin{tabular}{|c|c|c|c|}
\hline Site & Concentration $\left(\mathrm{nmol} \mathrm{L}^{-1}\right)$ & Efflux $\left(\mu \mathrm{mol} \mathrm{m}{ }^{-2} d^{-1}\right)$ & Reference \\
\hline Guanabara Bay (BR) & $19-11,803$ & $242-4798$ & Cotovicz et al. (2016) \\
\hline Pearl River (CN) & $23-2984$ & NM & Chen et al. (2008a) \\
\hline Rhine (NL) & $4-1437$ & $130^{*}$ & Middelburg et al. (2002) \\
\hline Oregon estuaries (US) & $6-697$ & $3-290$ & de Angelis and Scranton (1993) \\
\hline Loire (FR) & $16-671$ & $130^{*}$ & Middelburg et al. (2002) \\
\hline Humber (GB) & $13-667$ & $N M$ & Upstill-Goddard et al. (2000) \\
\hline Hudson River (US) & $65-660$ & -6 to 1370 & This study \\
\hline Tributaries & $105-5762$ & NM & \\
\hline Tyne (GB) & $13-654$ & $N M$ & Upstill-Goddard et al. (2000) \\
\hline Ivory Coast estuaries $(\mathrm{Cl})$ & $56-602$ & $54-877$ & Koné et al. (2010) \\
\hline Gironde (FR) & $4-559$ & $130^{*}$ & Middelburg et al. (2002) \\
\hline Pulicat Lake (IN) & $94-501$ & $54-280$ & Shalini et al. (2006) \\
\hline Scheldt (NL/BE) & $20-485$ & $130^{*}$ & Middelburg et al. (2002) \\
\hline Randers Fjord (DK) & $28-420$ & $70-410$ & Abril and Iversen (2002) \\
\hline Thames (GB) & $5-273$ & $130^{*}$ & Middelburg et al. (2002) \\
\hline Douro (PT) & $15-128$ & $130^{*}$ & Middelburg et al. (2002) \\
\hline Lupar and Saribas (MY) & $4-114$ & $23-89$ & Müller et al. (2016a) \\
\hline Elbe (DE) & $4-111$ & $130^{*}$ & Middelburg et al. (2002) \\
\hline Ems (DE) & $51-91$ & $130^{*}$ & Middelburg et al. (2002) \\
\hline North Creek (AU) & $44-89$ & $7-51$ & Maher et al. (2015) \\
\hline Rio San Pedro (ES) & $11-88$ & $34-150$ & Ferrón et al. (2007) \\
\hline Yangtze (CN) & $6-49$ & $41-225$ & Zhang et al. (2008) \\
\hline Sado (PT) & $37-40$ & $130^{*}$ & Middelburg et al. (2002) \\
\hline
\end{tabular}

List of reported values for methane $\left(\mathrm{CH}_{4}\right)$ surface concentrations and efflux ranges from predominantly macrotidal estuaries organized from highest to lowest maximum surface concentrations.

Efflux is reported as a range when data are available, otherwise as an average reported by the authors, or labeled as not measured (NM) if efflux was not determined.

*Average efflux determined with generalized global estuarine parameters (e.g., gas transfer velocity).

Cruz et al. 2017; Smith et al. 2017), but not in estuaries until recently (Garnier et al. 2013; Marescaux et al. 2018).

Increased microbial production of GHGs in response to DOC and DIN additions from wastewater inputs may be another possible mechanism, which was recently observed in a parallel study with NYC embayments (B. A. Brigham unpubl.). Similar conclusions about the importance of urban inputs in $\mathrm{CH}_{4}$ concentrations have been previously posited for the lower HRE (de Angelis and Scranton 1993). The magnitude of midchannel $\mathrm{CH}_{4}$ surface concentrations observed here were similar to those reported by de Angelis and Scranton (1993) but two times less than those reported by Hammond et al. (1977). Decreases in midchannel $\mathrm{CH}_{4}$ concentrations since Hammond et al. (1977) likely reflect the decline in anthropogenic inputs that has occurred during the intervening years (Brosnan et al. 2006).

\section{$p \mathrm{CO}_{2}$ surface values were strongly linked to multiple biogeochemical parameters}

Our combined $\mathrm{CH}_{4}, \mathrm{CO}_{2}$, and biogeochemical data enabled regression analyses relating GHG surface concentrations to anthropogenic indicators (e.g., enterococci) supporting H3 and allowing us to test the connection that has been speculated to exist in earlier publications. Here, we provide further data that support the link between urban wastewater input and enhanced $\mathrm{CH}_{4}$ and $\mathrm{CO}_{2}$ efflux. Multiple linear regression analyses demonstrated that enterococci concentrations (an indicator of anthropogenic inputs), as well as $\mathrm{O}_{2}$ saturation (indicating the balance between net autotrophic and heterotrophic activity), $\mathrm{NO}_{3}^{-}$, and temperature (a driver of microbial rates) explained the majority $\mathrm{CH}_{4}$ and $p \mathrm{CO}_{2}$ surface value variance in brackish surface waters.

Anthropogenic indicators, however, did not explain variation in GHG surface concentrations in the fresh region of the HRE. Rather, surface $p \mathrm{CO}_{2}$ values in freshwaters were positively correlated to oxygen saturation, river discharge, and temperature. In fact, the lowest $p \mathrm{CO}_{2}$ surface values in the HRE were observed in Albany (for all sampling periods) at the fresh terminus of the HRE. Overall, the regression models indicate that physical and chemical factors such as salinity, temperature, and oxygen saturation, as well as the anthropogenic indicator enterococci, and $\mathrm{NO}_{3}^{-}$concentrations were significant controlling factors of midchannel $\mathrm{CH}_{4}$ and $p \mathrm{CO}_{2}$ surface values. The regression models could be used to explore whether enterococci and 
Table 3. $\mathrm{CO}_{2}$ surface concentrations and efflux reported in estuaries.

\begin{tabular}{|c|c|c|c|}
\hline Site & Concentration ( $\mu \mathrm{atm}$ ) & Efflux $\left(\mathrm{mmol} \mathrm{m} \mathrm{m}^{-2} \mathrm{~d}^{-1}\right)$ & Reference \\
\hline Recife (BR) & $276-22,470$ & $N M$ & Noriega et al. (2013) \\
\hline Scheldt (NL/BE) & $125-9425$ & $19^{*}$ & Frankignoulle et al. (1998) \\
\hline Ivory Coast estuaries (Cl) & 0-9000 & $20-34$ & Koné et al. (2009) \\
\hline Pearl River (CN) & $560-8350$ & 131 & Guo et al. (2009) \\
\hline Satilla River (US) & $400-8200$ & 116 & Cai and Wang (1998) \\
\hline Sado (PT) & $575-5700$ & $11^{*}$ & Frankignoulle et al. (1998) \\
\hline Lupar and Saribas (MY) & $297-5504$ & $63-95$ & Müller et al. (2016b) \\
\hline Thames (GB) & $505-5200$ & $27^{*}$ & Frankignoulle et al. (1998) \\
\hline Yangtze (CN) & $200-4600$ & $0-266$ & Zhai et al. (2007) \\
\hline Rio San Pedro (ES) & $380-3760$ & $14^{*}$ & Ferrón et al. (2007) \\
\hline Ems (DE/NE) & $560-3755$ & $24^{*}$ & Frankignoulle et al. (1998) \\
\hline Guanabara Bay (BR) & $22-3715$ & -50 to 85 & Cotovicz et al. (2015) \\
\hline York River (US) & $113-3467$ & -6 to 107 & Raymond et al. (2000) \\
\hline Randers Fjord (KD) & $220-3440$ & -5 to 53 & Gazeau et al. (2005) \\
\hline Altamaha Sound (US) & $493-3380$ & $13^{\dagger}$ & Jiang et al. (2008) \\
\hline North Creek (AU) & $600-3000$ & $19-70$ & Maher et al. (2015) \\
\hline Loire (FR) & 630-2910 & $24^{*}$ & Abril et al. (2003) \\
\hline Gironde (FR) & $465-2860$ & $11^{*}$ & Frankignoulle et al. (1998) \\
\hline Duplin River (US) & $500-2500$ & $58^{*}$ & Wang and Cai (2004) \\
\hline Doboy Sound (US) & $375-2400$ & $33^{\dagger}$ & Jiang et al. (2008) \\
\hline Sapelo Sound (US) & $375-2400$ & $29^{\dagger}$ & Jiang et al. (2008) \\
\hline Douro (PT) & $1330-2200$ & $28^{*}$ & Frankignoulle et al. (1998) \\
\hline Tamer (GB) & $380-2200$ & $27^{*}$ & Frankignoulle et al. (1998) \\
\hline Oyster (US) & $84-2003$ & $12^{\dagger}$ & Hunt et al. (2011) \\
\hline Hudson River (US) & 460-1930 & 1-196 & This study \\
\hline Tributaries & $179-5530$ & $N M$ & \\
\hline Rhine (NE) & 545-1990 & $15^{*}$ & Frankignoulle et al. (1998) \\
\hline Bellamy (US) & $148-1515$ & $13^{\dagger}$ & Hunt et al. (2011) \\
\hline Cocheco (US) & $84-1187$ & $10^{\dagger}$ & Hunt et al. (2011) \\
\hline Elbe (DE) & $580-1100$ & $19^{*}$ & Frankignoulle et al. (1998) \\
\hline Shark River (US) & $1285^{\ddagger}$ & $44^{\dagger}$ & Koné and Borges (2008) \\
\hline
\end{tabular}

List of reported values for carbon dioxide $\left(\mathrm{pCO}_{2}\right)$ surface concentrations and efflux ranges from predominantly macrotidal estuaries organized from highest to lowest maximum surface concentrations which have been summarized previously by a combination of Borges and Abril (2011) and Chen et al. (2013).

Efflux is reported as a range when data are available, otherwise as an average presented by the authors, or labeled as not measured (NM) if efflux was not determined.

*Average values procured from Borges and Abril (2011).

Average values procured from Chen et al. (2013).

${ }^{\ddagger}$ Average $p \mathrm{CO}_{2}$ is reported as original data source is unavailable.

perhaps other anthropogenic indicators (e.g., micropolluants) explain patterns of GHG concentration and efflux data in other urbanized estuaries.

\section{p $\mathrm{CO}_{2}, \mathrm{DOC}, \mathrm{NO}_{3}^{-}$, and $\mathrm{NH}_{4}^{+}$spatial and temporal patterns in the HRE}

Midchannel $p \mathrm{CO}_{2}$ surface values were similar in the lower estuary and midestuary (Regions 1, 2, and 3) with significantly lower values observed in the fresh urban region. In tidal estuaries worldwide (Chen et al. 2012, 2013) including previous research in the HRE (Raymond et al. 1997), higher estuarine $p \mathrm{CO}_{2}$ values are typically observed in the freshwater terminus or the upper estuary, in contrast to the results reported here. In general, the highest $p \mathrm{CO}_{2}$ concentrations in fresh estuarine waters have been explained by the large delivery of organic matter inputs from terrestrial surface runoff and subsequent heterotrophic consumption (McCallister et al. 2004; Cole and Caraco 2006). In addition, greater rates of biological productivity $\left(\mathrm{CO}_{2}\right.$ consumption) in brackish waters and the dilution of supersaturated $\mathrm{pCO}_{2}$ riverine waters with less saturated coastal waters (Chen et al. 2008a,b; Guo et al. 2009) deplete $p \mathrm{CO}_{2}$ in the brackish and saline waters. The reasons for the difference in $p \mathrm{CO}_{2}$ patterns observed between Raymond et al. (1997) and our own data may be explained by the relatively 
Table 4. Midchannel surface sample measurements.

\begin{tabular}{|c|c|c|c|c|c|}
\hline Region* & $\begin{array}{l}\mathrm{CH}_{4} \text { conc. } \\
\left(\mathrm{nmol} \mathrm{L} \mathrm{L}^{-1}\right)\end{array}$ & $\begin{array}{l}p \mathrm{CO}_{2} \text { value } \\
\text { ( } \mu \text { atm })\end{array}$ & $\begin{array}{c}\text { Enterococci } \\
\text { (most probable numbers) }\end{array}$ & $\mathrm{DOC}\left(\mathrm{mg} \mathrm{L}^{-1}\right)$ & $\mathrm{NO}_{3}^{-}\left(\mathrm{mg} \mathrm{L}^{-1}\right)$ \\
\hline \multicolumn{6}{|c|}{ Surface measurements } \\
\hline 1 & $309(20)$ & $1203(74)$ & $12(4)$ & $2.6(0.1)$ & $0.4(0.0)$ \\
\hline 2 & $182(8)$ & $1187(75)$ & $6(2)$ & $2.9(0.1)$ & $0.4(0.0)$ \\
\hline 3 & $217(15)$ & $1327(51)$ & $52(39)$ & $3.3(0.1)$ & $0.5(0.0)$ \\
\hline 4 & $284(29)$ & $868(51)$ & $337(125)$ & $3.5(0.1)$ & $0.5(0.0)$ \\
\hline Region* & Temp. $\left({ }^{\circ} \mathrm{C}\right)$ & Salinity & $\mathrm{O}_{2}$ sat. (\%) & $\begin{array}{c}\text { Turbidity } \\
\text { (nephelometric turbidity } \\
\text { units) }\end{array}$ & $\begin{array}{c}\text { Chl } a \text { (relative } \\
\text { fluorescence } \\
\text { units) }\end{array}$ \\
\hline \multicolumn{6}{|c|}{ Probe measurements } \\
\hline 1 & $21.4(0.7)$ & $15.2(1.1)$ & $87.8(2.1)$ & $23.3(4.3)$ & $5.7(1.3)$ \\
\hline 2 & $23.0(0.6)$ & $5.5(0.5)$ & $91.8(1.4)$ & $19.0(1.4)$ & $8.3(1.1)$ \\
\hline 3 & $21.9(0.6)$ & $0.2(0.0)$ & $91.2(1.1)$ & 30.7 (2.9) & $3.7(0.5)$ \\
\hline 4 & $21.7(0.8)$ & $0.1(0.0)$ & $101.0(1.5)$ & $33.6(6.4)$ & $2.1(0.4)$ \\
\hline
\end{tabular}

Parameters include methane $\left(\mathrm{CH}_{4}\right)$ concentrations, carbon dioxide $\left(p \mathrm{CO}_{2}\right)$ values, DOC, nitrate $\left(\mathrm{NO}_{3}^{-}\right)$, oxygen $\left(\mathrm{O}_{2}\right)$ saturation, and Chl $a$. Ammonium $\left(\mathrm{NH}_{4}^{+}\right)$concentrations were below the limit of detection $(<0.15 \mathrm{ppm})$.

Values in parenthesis are standard errors.

*The Hudson River was divided into four regions: region 1 (brackish urban, RK 0-19), region 2 (brackish suburban/rural, RK 30-69), region 3 (fresh suburban/rural, RK 84-182), and region 4 (fresh urban, RK 197-245) to bin data by both salinity and anthropogenic input.

lower river flow (50\% compared to our study) during the Raymond et al. (1997) study (USGS, accessed April 2018, https://waterdata.usgs.gov/nwis/uv?site_no=01358000). Lower river flow would increase water residence time-increasing sedimentation of organic matter, enhancing heterotrophy (Crawford et al. 2016), and biogeochemical transformations, as well as facilitating the accumulation of GHGs (Raymond et al. 2012; Borges et al. 2018).

Month-to-month variations in $\mathrm{pCO}_{2}$ surface values were similar to those in previous studies conducted in the brackish (Griffith and Raymond 2011) and fresh HRE (Raymond et al. 1997; Cole and Caraco 2001), and similarly the $p \mathrm{CO}_{2}$ values varied by month. A similar enhancement was not observed with $\mathrm{CH}_{4}$ surface concentrations during warmer months. $\mathrm{NO}_{3}^{-}$, but not $\mathrm{NH}_{4}^{+}$, was detected throughout the HRE including tributaries and nearshore sites surrounding NYC. High oxygen saturation concentrations observed (>87\%) for all cruises may account for detectable $\mathrm{NO}_{3}^{-}$concentrations.

\section{Efflux estimates vary with wind speed}

GHG efflux calculations in estuarine systems are characterized by significant uncertainties, which have led to large ranges in reported worldwide values (Raymond and Cole 2001; Zappa et al. 2003; Borges and Abril 2011). Efflux is dependent on the concentration difference between the surface and atmosphere of each gas as well as the turbulence mediated transfer

Table 5. Tributary surface sample measurements.

\begin{tabular}{|c|c|c|c|c|c|}
\hline$\underline{\text { Region* }}$ & $\mathrm{CH}_{4}$ conc. (nmol L ${ }^{-1}$ ) & $p \mathrm{CO}_{2}$ value ( $\left.\mu \mathrm{atm}\right)$ & Enterococci (MPNs) & $\mathrm{DOC}\left(\mathrm{mg} \mathrm{L}^{-1}\right)$ & $\mathrm{NO}_{3}^{-}\left(\mathrm{mg} \mathrm{L}^{-1}\right)$ \\
\hline \multicolumn{6}{|c|}{ Surface measurements } \\
\hline 1 & $957(176)$ & 1925 (109) & $157(56)$ & $2.6(0.1)$ & $0.3(0.0)$ \\
\hline 3 & $633(93)$ & $1022(81)$ & $197(120)$ & $3.3(0.3)$ & $0.3(0.1)$ \\
\hline Region* $^{*}$ & Temp. $\left({ }^{\circ} \mathrm{C}\right)$ & Salinity & $\mathrm{O}_{2}$ sat. (\%) & Turbidity (NTUs) & Chl $a$ (RFUs) \\
\hline \multicolumn{6}{|c|}{ Probe measurements } \\
\hline 1 & $21.0(0.6)$ & $20.7(0.7)$ & $79(2.1)$ & $13.4(1.7)$ & $12.1(1.3)$ \\
\hline 3 & $21.9(0.9)$ & $0.1(0.0)$ & $101(1.1)$ & $10.9(2.3)$ & $4.8(0.5)$ \\
\hline
\end{tabular}

Parameters include methane $\left(\mathrm{CH}_{4}\right)$ concentrations, carbon dioxide $\left(p \mathrm{CO}_{2}\right)$ values, $\mathrm{DOC}$, nitrate $\left(\mathrm{NO}_{3}^{-}\right)$, oxygen $\left(\mathrm{O}_{2}\right)$ saturation, and $\left.\mathrm{Chl} a\right)$. Ammonium $\left(\mathrm{NH}_{4}^{+}\right)$concentrations were below the limit of detection $(<0.15 \mathrm{ppm})$.

Values in parenthesis are standard errors.

*The Hudson River was divided into four regions: region 1 (brackish urban, RK 0-19), region 2 (brackish suburban/rural, RK 30-69), region 3 (fresh suburban/rural, RK 84-182), and region 4 (fresh urban, RK 197-245) to bin data by both salinity and anthropogenic input. Regions 2 and 4 had no accessible tributaries-data from the nearshore sites were not used for analysis and can be found in Supporting Information Table S10. 

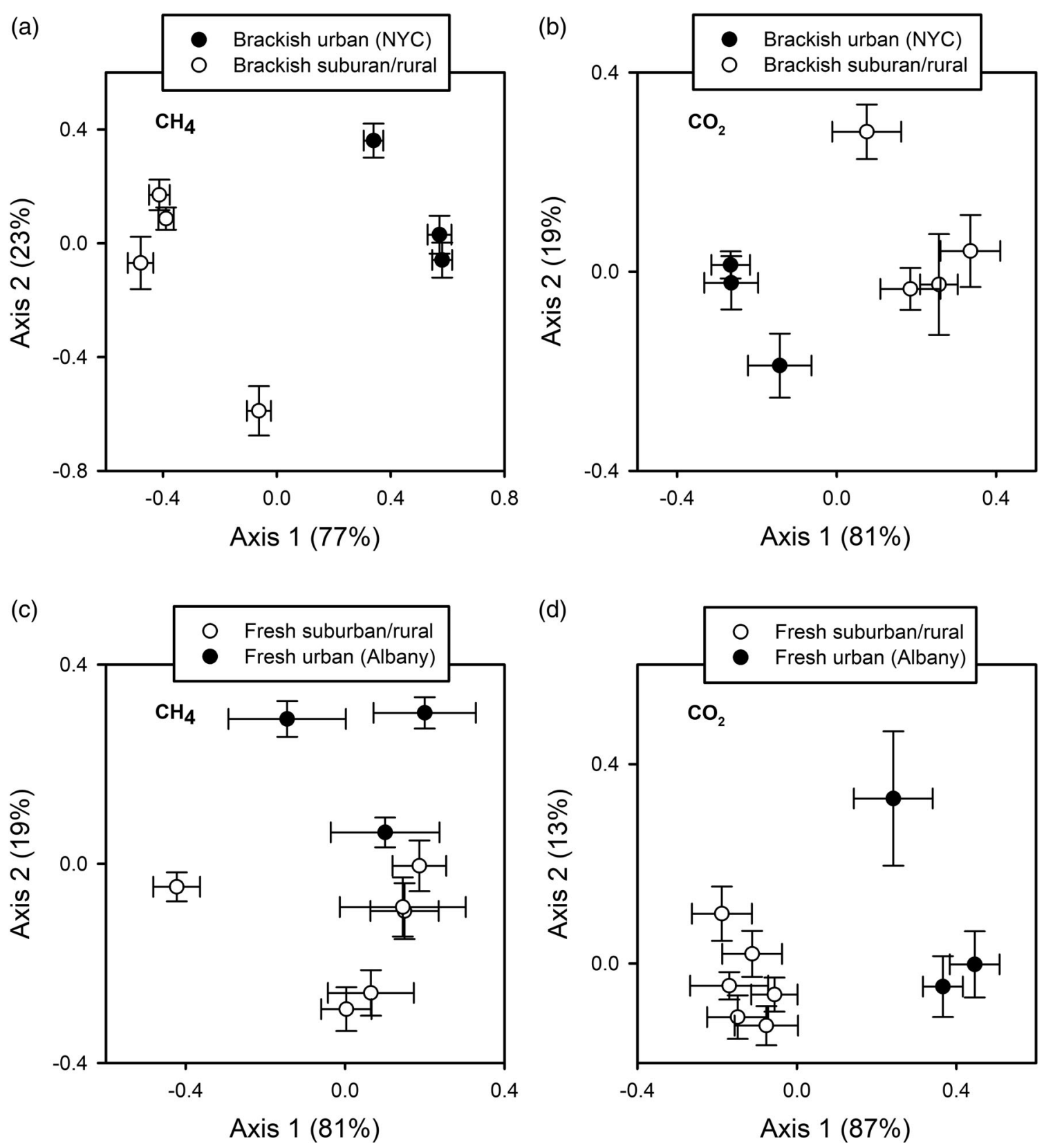

Fig. 5. Canonical correlation analyses of $\mathrm{CH}_{4}$ and $\mathrm{CO}_{2}$ surface concentrations to biogeochemical parameters in the $\mathrm{HRE}$. Analyses includes: (a) $\mathrm{CH}_{4}$ surface concentrations in the brackish (RK 0-69) $\mathrm{HRE},(\mathbf{b}) \mathrm{CH}_{4}$ surface concentrations in the fresh (RK 84-244) $\mathrm{HRE},(\mathbf{c}) p C \mathrm{O}_{2}$ surface values in the brackish (RK 0-69) HRE, and (d) $p \mathrm{CO}_{2}$ surface values in the fresh (RK 84-244) HRE. Data illustrate similarities in correlations between GHG concentrations and biogeochemical parameters for sampling sites (i.e., sites within each region group together in multivariate space). Error bars are standard error of the mean.

(or gas transfer velocity) as dictated by physical conditions (Wanninkhof et al. 1993). We used both daily and weekly wind speeds from a series of three towers with meteorological equipment above $10 \mathrm{~m}$ to calculate gas transfer velocity values. The accuracy of these values is critical as wind speed is typically utilized in a power or log function to ultimately determine efflux. Our methodology established potential ranges of $\mathrm{CH}_{4}$ and $\mathrm{CO}_{2}$ efflux rather than attempting to select a single model or gas transfer velocity value. In fact, the variability in efflux values calculated using different models created enough uncertainty in spatial and temporal efflux patterns that we chose to focus instead on the analysis of surface concentration patterns described above. In our study, we did not attempt to select the "best" gas transfer velocity model, but instead attempted to highlight the importance of differing assumptions in the existing models, while constraining potential ranges of $\mathrm{CH}_{4}$ and $\mathrm{CO}_{2}$ efflux. Both comprehensive spatial coverage of wind speed (at each measurement site) and greater temporal coverage to 
Table 6. $\mathrm{CH}_{4}$ and $\mathrm{CO}_{2}$ efflux from HRE.

\begin{tabular}{|c|c|c|c|c|c|c|}
\hline Region* & $\begin{array}{c}\text { River } \\
\text { dist. (km) }\end{array}$ & $\begin{array}{l}\text { Area } \\
\left(\mathrm{km}^{2}\right)\end{array}$ & $\begin{array}{c}\mathrm{CH}_{4} \text { efflux } \\
\left(\mu \mathrm{mol} \mathrm{m} \mathbf{m}^{-2} \mathrm{~d}^{-1}\right)\end{array}$ & $\begin{array}{c}\mathrm{CO}_{2} \text { efflux } \\
\left(\mathrm{mmol} \mathrm{m} \mathbf{m}^{-2} \mathrm{~d}^{-1}\right)\end{array}$ & $\begin{array}{c}\mathrm{CO}_{2} \mathrm{e} \text { efflux } \\
\left(\mathrm{mmol} \mathrm{m} \mathrm{m}^{-2} \mathrm{~d}^{-1}\right)\end{array}$ & 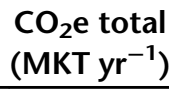 \\
\hline 1 & $0-20$ & 27 & $292(84)$ & $29(5)$ & $36(6)$ & $16(2)$ \\
\hline 2 & $20-69$ & 124 & $122(15)$ & $35(6)$ & $38(6)$ & $076(12)$ \\
\hline 3 & 69-197 & 130 & 179 (33) & $41(6)$ & $45(5)$ & 95 (13) \\
\hline 4 & $197-245$ & 19 & $123(23)$ & $13(2)$ & $16(2)$ & $5(1)$ \\
\hline Total & $0-245$ & 300 & - & - & - & $177(16)$ \\
\hline
\end{tabular}

Values in parenthesis are the standard error of mean.

MKT represents metric kilotons and $\mathrm{CO}_{2}$ e represents $\mathrm{CO}_{2}$ equivalents.

*The Hudson River was divided into four regions: region 1 (brackish urban, RK 0-19), region 2 (brackish suburban/rural, RK 30-69), region 3 (fresh suburban/rural, RK 84-182), and region 4 (fresh urban, RK 197-245) to bin data by both salinity and anthropogenic input.

better quantify variation in GHG surface concentrations would improve the accuracy of our efflux values.

\section{The entire HRE was a source of both $\mathrm{CO}_{2}$ and $\mathrm{CH}_{4}$}

The vast majority (>99\%) of $\mathrm{CH}_{4}$ and $\mathrm{CO}_{2}$ surface measurements, including all midchannel measurements, showed supersaturation. The HRE was thus a source of GHG to the atmosphere in all locations and times. Our comparison of $\mathrm{CH}_{4}$ and $p \mathrm{CO}_{2}$ surface values within the HRE to estuaries worldwide demonstrated that the range of $\mathrm{CH}_{4}$ concentrations, as well as average efflux values, is among the top quartile of reported values (Middelburg et al. 2002; Borges and Abril 2011). High concentrations and efflux values were observed despite the short residence time of the HRE, especially in saline waters surrounding NYC, compared to other studied estuaries likely due in part to wastewater inputs (Howarth et al. 2006). Overall, the higher concentrations of $\mathrm{CH}_{4}$ in sewage delivery areas in addition to the correlation between $\mathrm{CH}_{4}$ and enterococci concentrations indicate that anthropogenic additions resulted in a higher baseline of $\mathrm{CH}_{4}$ concentration (and likely flux) than would otherwise exist in an undisturbed HRE. The two estuaries with considerably higher $\mathrm{CH}_{4}$ surface concentrations, Guanabara Bay and Pearl River estuaries, also have a history of extremely high anthropogenic inputs (Chen et al. 2008a; Cotovicz et al. 2016). $\mathrm{CH}_{4}$ surface concentrations were greater, on average, in tributaries than in other sites, corroborating high values reported in small rivers and streams (Butman and Raymond 2011; McGinnis et al. 2016; Sawakuchi et al. 2017), especially those impacted directly by wastewater or agricultural inputs (Rajkumar et al. 2008; Garnier et al. 2013; Borges et al. 2018; Drake et al. 2018).

Conversely, $p \mathrm{CO}_{2}$ surface and efflux values observed here are among the bottom quartile worldwide of reported estuarine values summarized by Chen et al. (2013). The range of $\mathrm{CO}_{2}$ efflux (13-35 mmol $\mathrm{CO}_{2} \mathrm{~m}^{-2} \mathrm{~d}^{-1}$ ) values observed was well below both the range $\left(86-105 \mathrm{mmol} \mathrm{CO} \mathrm{m}^{-2} \mathrm{~d}^{-1}\right)$ determined from the 2004 to 2005 data sets produced largely from polluted European estuaries (Borges 2005; Borges et al. 2005) as well as more recent averages $\left(48-58 \mathrm{mmol} \mathrm{CO}_{2} \mathrm{~m}^{-2} \mathrm{~d}^{-1}\right.$ ) sourced from a larger diversity of estuaries (Laruelle et al.
2010). However, the values here are similar to the average values observed from the estuaries $(n=15)$ along the eastern seaboard of the United States (Chen et al. 2013). These worldwide differences are driven by two main factors: (1) European estuaries are consistently significantly windier $(2-4 \times)$ than those found in North America, increasing average efflux values and (2) extremely high $p \mathrm{CO}_{2}$ concentrations are largely reported in European, Chinese, and Brazilian estuaries.

Using average values for each region, we calculated that the tidal HRE annually releases a total of 191 metric kiloton $\mathrm{CO}_{2}$ equivalents (Table 6). This represents $8 \%$ of NYC's reported wastewater treatment GHG footprint (City of New York, Accessed April 2018, https://www.dec.ny.gov/docs/administration_pdf/nycghg. pdf) and demonstrates the large impact of urban inputs. However, this estimate of total GHG efflux was based only on midchannel data. Given higher surface GHG concentrations in tributaries, combined with greater frictional forces and higher gas transfer velocities, our total efflux value is likely an underestimate.

\section{Hotspots and hot moments enhance production estimates and add measurement uncertainties}

These results build upon those reported by Griffith and Raymond (2011) where net heterotrophy in the saline HRE was found to be dictated predominantly by available DOC from anthropogenic inputs. Our data illustrate that the higher baseline of GHG production in urban areas is due to enhanced DOC and DIN loading from terrestrial sources. The nature of anthropogenic inputs in the HRE, which are delivered by submerged outfalls that flow following both sewage treatment and precipitation events (NYCDEP 2004), likely lead to both "hotspots" and "hot moments" of microbial heterotrophic activity (McClain et al. 2003). The majority of heterotrophy in anaerobic soils/sediments is often restricted to these "hot moments" (Guenet et al. 2010). Data focused on the impacts of anthropogenic (and natural) inputs in relevant scales are critically important areas for future study. In addition, we did not measure $\mathrm{N}_{2} \mathrm{O}$, a GHG with $298 \times$ warming potential compared with $\mathrm{CO}_{2}$ over a 100-yr period (Ciais et al. 2013). Quantifying $\mathrm{N}_{2} \mathrm{O}$ is of major import for estuaries as denitrification has been 
demonstrated to be an important GHG source (Marescaux et al. 2018) in urban estuaries and surrounding wetlands due to high anthropogenic $\mathrm{NO}_{3}^{-}$inputs (Schlesinger 2009; Doney 2010).

\section{Conclusions}

The HRE was a source of both $\mathrm{CH}_{4}$ and $\mathrm{CO}_{2}$ to the atmosphere throughout the sampling season, with the highest $\mathrm{CH}_{4}$ concentrations observed in urbanized regions, notably the major sewage delivery areas of NYC. This comprehensive study was unique in that it linked GHG surface values to anthropogenic indictors supporting additional estuarine studies that demonstrated that urban influence enhances GHG production from estuaries. The urban influence on estuarine GHG production has rarely been explicitly linked from prior field measurements (Burgos et al. 2015).

Our study demonstrates that regression models can explain a very high percentage of the variability in $p \mathrm{CO}_{2}$ and $\mathrm{CH}_{4}$ surface values in this complex estuary with multiple natural and anthropogenic driven gradients. Moreover, the parameters used for these models are relatively simple to measure. More robust measurements including complete diel and seasonal cycle sampling as well as expanded testing in other estuaries (urban and otherwise) could assist with model validation. Using such models, the need for relatively expensive and time-consuming GHG measurements decreases, which would facilitate GHG flux estimates from estuaries, especially those located in the undeveloped world (Borges and Abril 2011). Our data demonstrate that inputs from a coastal megacity partially explain GHG concentrations in receiving estuarine waters. Multifactor data sets like this one provide additional insight into the processes that dictate urban estuarine GHG dynamics imparting scientists and management with more tools to better estimate estuarine urban climate impacts.

\section{References}

Abril, G., H. Etcheber, A. V. Borges, and M. Frankignoulle. 2000. Excess atmospheric carbon dioxide transported by rivers into the Scheldt estuary. C. R. Acad. Sci. Ser. IIA Earth Planet. Sci. 330: 761-768. doi:10.1016/S1251-8050(00)00231-7

Abril, G., and N. Iversen. 2002. Methane dynamics in a shallow non-tidal estuary (Randers Fjord, Denmark). Mar. Ecol. Prog. Ser. 230: 171-181. doi:10.3354/meps230171

Abril, G., H. Etcheber, B. Delille, M. Frankignoulle, and A. Borges. 2003. Carbonate dissolution in the turbid and eutrophic Loire estuary. Mar. Ecol. Prog. Ser. 259: 129-138. doi:10.3354/meps259129

Alshboul, Z., J. Encinas-Fernandez, H. Hofmann, and A. Lorke. 2016. Export of dissolved methane and carbon dioxide with effluents from municipal wastewater treatment plants. Environ. Sci. Technol. 50: 5555-5563. doi:10.1021/acs.est. 5 b04923
American Public Health Association. 2012. 5310 Total organic carbon (TOC), p. 19-24. In R. W. Rice, R. B. Baird, A. D. Eaton, and L. S. Clescer [eds.], Standard methods for the examination of water and wastewater. American Public Health Association/American Water Works Association/ Water Environment Federation.

Bange, H. W. 2006. Nitrous oxide and methane in European coastal waters. Estuar. Coast. Shelf Sci. 70: 361-374. doi: 10.1016/0304-4203(96)00011-4

Bartlett, K. B., D. S. Bartlett, R. C. Harriss, and D. I. Sebacher. 1987. Methane emissions along a salt marsh salinity gradient. Biogeochemistry 4: 183-202. doi:10.1007/BF02187365

Bianchi, T. 2007. Estuarine Science and Biogeochemical Cycles, p. 3-10. In Biogeochemistry of estuaries. Oxford Univ. Press.

Bokuniewicz, H. 2006. Sedimentary processes in the Hudson River Estuary, p. 39-50. In J. S. Levinton and J. R. Waldman [eds.], The Hudson River Estuary. Cambridge Univ. Press.

Borges, A. V. 2005. Do we have enough pieces of the jigsaw to integrate $\mathrm{CO} 2$ fluxes in the coastal ocean? Estuaries 28: 3-27. doi:10.1007/BF02732750

Borges, A. V., B. Delille, and M. Frankignoulle. 2005. Budgeting sinks and sources of $\mathrm{CO}_{2}$ in the coastal ocean: Diversity of ecosystems counts. Geophys. Res. Lett. 32: L14601. doi: 10.1029/2005GL023053

Borges, A. V., and G. Abril. 2011. Carbon dioxide and methane dynamics in estuaries, p. 119-161. In E. Wolanski and D. S. McLusky [eds.], Treatise on estuarine and coastal science. Academic Press.

Borges, A. V., and others. 2018. Effects of agricultural land use on fluvial carbon dioxide, methane and nitrous oxide concentrations in a large European river, the Meuse (Belgium). Sci. Total Environ. 610-611: 342-355. doi:10.1016/j. scitoenv.2017.08.047

TYPO Brosnan, M. T., A. Stoddard, and L. J. Hetling. 2006. Hudson River sewage inputs and impacts: Past and present, p. 335-348. In J. S. Levinton and J. R. Waldman [eds.]., The Hudson River Estuary, Cambridge Univ. Press.

Burgos, M., A. Sierra, T. Ortega, and J. M. Forja. 2015. Anthropogenic effects on greenhouse gas $\left(\mathrm{CH}_{4}\right.$ and $\left.\mathrm{N}_{2} \mathrm{O}\right)$ emissions in the Guadalete River Estuary (SW Spain). Sci. Total Environ. 503-504: 179-189. doi:10.1016/j.scitotenv.2014.06.038

Butman, D., and P. A. Raymond. 2011. Significant efflux of carbon dioxide from streams and rivers in the United States. Nat. Geosci. 4: 839-842. doi:10.1038/ngeo1294

Cai, W.-J., and Y. Wang. 1998. The chemistry, fluxes, and sources of carbon dioxide in the estuarine waters of the Satilla and Altamaha Rivers, Georgia. Limnol. Oceanogr. 43: 657-668. doi:10.4319/lo.1998.43.4.0657

Capone, D. G., and R. P. Kiene. 1988. Comparison of microbial dynamics in marine and freshwater sediments: Contrasts in anaerobic carbon catabolism. Limnol. Oceangr. 33: 725-749. doi:10.4319/lo.1988.33.4part2.0725

Chen, C.-T. A., W. Zhai, and M. Dai. 2008a. Riverine input and air-sea $\mathrm{CO}_{2}$ exchanges near the Changjiang (Yangtze 
River) Estuary: Status quo and implication on possible future changes in metabolic status. Cont. Shelf Res. 28: 1476-1482. doi:10.1016/j.csr.2007.10.013

Chen, C.-T. A., and others. 2008b. Hydrogeochemistry and greenhouse gases of the Pearl River, its estuary and beyond. Quat. Int. 186: 79-90. doi:10.1016/j.quaint.2007.08.024

Chen, C.-T. A., T.-H. Huang, Y.-H. Fu, Y. Bai, and X. He. 2012. Strong sources of $\mathrm{CO}_{2}$ in upper estuaries become sinks of $\mathrm{CO}_{2}$ in large river plumes. Curr. Opin. Environ. Sustain. 4: 179-185. doi:10.1016/j.cosust.2012.02.003

Chen, C.-T. A., T.-H. Huang, Y.-C. Chen, Y. Bai, X. He, and Y. Kang. 2013. Air-sea exchanges of $\mathrm{CO}_{2}$ in the world's coastal seas. Biogeosciences 10: 6509-6544. doi:10.5194/ bg-10-6509-2013

Ciais, P., and others. 2013. Carbon and other biogeochemical cycles, p. 365-570. In T. F. Stocker et al. [eds.], Climate change 2013: The physical science basis. Contribution of working group I to the fifth assessment report of the Intergovernmental Panel on Climate Change. Cambridge Univ. Press.

Cole, J. J., and N. F. Caraco. 2001. Carbon in catchments: Connecting terrestrial carbon losses with aquatic metabolism. Mar. Freshw. Res. 52: 101-110. doi:10.1071/MF00084

Cole, J. J., and N. F. Caraco. 2006. Primary production and its regulation in the tidal-freshwater Hudson River, p. 107-120. In J. S. Levinton and J. R. Waldman [eds.], The Hudson River Estuary. Cambridge Univ. Press.

Cooper, J. C., F. R. Cantelmo, and C. E. Newton. 1988. Overview of the Hudson River Estuary, p. 11-24. In L. W. Barnthouse, R. J. Klauda, D. S. Vaughan, and R. L. Kendal [eds.], Science, law and Hudson River power plants: A case study in environmental impact assessment. American Fisheries Society.

Cotovicz, L. C., Jr., B. A. Knoppers, N. Brandini, S. J. Costa Santos, and G. Abril. 2015. A large $\mathrm{CO}_{2}$ sink enhanced by eutrophication in a tropical coastal embayment (Guanabara Bay, Rio de Janeiro, Brazil). Biogeosciences 12: 6125-6146. doi:10.5194/bg-12-6125-2915

Cotovicz, L. C., Jr., B. A. Knoppers, N. Brandini, D. Poirier, S. J. Costa Santos, and G. Abril. 2016. Spatio-temporal variability of methane $\left(\mathrm{CH}_{4}\right)$ concentrations and diffusive fluxes from a tropical coastal embayment surrounded by a large urban area (Guanabara Bay, Rio de Janeiro, Brazil). Limnol. Oceanogr. 61: S238-S252. doi:10.1002/lno.10298

Crawford, J. T., L. C. Loken, E. H. Stanley, E. G. Stets, M. M. Dornblaser, and R. G. Striegl. 2016. Basin scale controls on $\mathrm{CO}_{2}$ and $\mathrm{CH}_{4}$ emissions from the Upper Mississippi River. Geophys. Res. Lett. 43: 1973-1979. doi:10.1002/2015GL 067599

de Angelis, M. A., and M. I. Scranton. 1993. Fate of methane in the Hudson River and Estuary. Global Biogeochem. Cycles 7: 509-523. doi:10.1029/93GB01636

Doane, T. A., and W. R. Horwáth. 2003. Spectrophotometric determination of nitrate with a single reagent. Anal. Lett. 36: 2713-2722. doi:10.1081/AL-120024647
Doney, S. C. 2010. The growing human footprint on coastal and open-ocean biogeochemistry. Science 328: 1512-1516. doi:10.1126/science. 1185198

Drake, T. W., P. A. Raymond, and R. G. M. Spencer. 2018. Terrestrial carbon inputs to inland waters: A current synthesis of estimates and uncertainty. Limnol. Oceanogr.: Lett. 3: 132-142. doi:10.1002/lol2.10055

Ferrón, S., T. Ortega, A. Gómez-Parra, and J. M. Forja. 2007. Seasonal study of dissolved $\mathrm{CH}_{4}, \mathrm{CO}_{2}$ and $\mathrm{N}_{2} \mathrm{O}$ in a shallow tidal system of the Bay of Cádiz (SW Spain). J. Mar. Syst. 66: 244-257. doi:10.1016/j.jmarsys.2006.03.021

Frankignoulle, M., and others. 1998. Carbon dioxide emission from European estuaries. Science 282: 434-436. doi: 10.1126/science.282.5388.434

Garnier, J., and others. 2013. Budget of methane emissions from soils, livestock and the river network at the regional scale of the Seine basin (France). Biogeochemistry 116: 199-214. doi:10.1007/s10533-013-9845-1

Gazeau, F., and others. 2005. Net ecosystem metabolism in a micro-tidal estuary (Randers Fjord, Denmark): Evaluation of methods. Mar. Ecol. Prog. Ser. 301: 23-41. doi:10.3354/ meps301023

Geyer, W. R., and R. Chant. 2006. The physical oceanography processes in the Hudson River Estuary, p. 24-38. In J. S. Levinton and J. R. Waldman [eds.], The Hudson River Estuary. Cambridge Univ. Press.

Griffith, D. R., and P. A. Raymond. 2011. Multiple-source heterotrophy fueled by aged organic carbon in an urbanized estuary. Mar. Chem. 124: 14-22. doi:10.1016/j.marchem.2010.11.003

Guenet, B., M. Danger, L. Abbadie, and G. Lacroix. 2010. Priming effect: Bridging the gap between terrestrial and aquatic ecology. Ecology 91: 2850-2861. doi:10.1890/09-1968.1

Guo, X., M. Dai, W. Zhai, W.-J. Cai, and B. Chen. 2009. $\mathrm{CO}_{2}$ flux and seasonal variability in a large subtropical estuarine system, the Pearl River Estuary, China. Eur. J. Vasc. Endovasc. Surg. 114. doi:10.1029/2008JG000905

Hammond, D. E., H. J. Simpson, and G. Matheiu. 1977. Radon 222 distribution and transport across the sediment-water interface in the Hudson River Estuary. J. Geophys. Res. 82: 3913-3920. doi:10.1029/JC082i027p03913

Ho, D. T., C. S. Law, M. J. Smith, P. Schlosser, M. Harvey, and P. Hill. 2006. Measurements of air-sea gas exchange at high wind speeds in the Southern Ocean: Implications for global parameterizations. Geophys. Res. Lett. 33: L16611. doi: 10.1029/2006GL026817

Ho, D. T., P. Schlosser, and P. M. Orton. 2011. On factors controlling air-water gas exchange in a large tidal river. Estuaries Coast. 34: 1103-1116. doi:10.1007/s12237-0119396-4

Howarth, R. W., R. Schneider, and D. Swaney. 1996. Metabolism and organic carbon fluxes in the tidal freshwater Hudson River. Estuaries 19: 848-865. doi:10.2307/1352302

Howarth, R. W., R. Marino, D. P. Swaney, and E. W. Boyer. 2006. Wastewater and watershed influences on primary 
productivity and oxygen dynamics in the lower Hudson River Estuary, p. 121-139. In J. S. Levinton and J. R. Waldman [eds.], The Hudson River Estuary. Cambridge Univ. Press.

Hunt, C. W., J. E. Salisbury, D. Vandemark, and W. McGillis. 2011. Contrasting carbon dioxide inputs and exchange in three adjacent New England estuaries. Estuaries Coast. 34: 68-77. doi:10.1007/s12237-010-9299-9

Jiang, L.-Q., W.-J. Cai, and Y. Wang. 2008. A comparative study of carbon dioxide degassing in river- and marinedominated estuaries. Limnol. Oceanogr. 53: 2603-2615. doi:10.4319/1o.2008.53.6.2603

Kempe, S. 1984. Sinks of the anthropogenically enhanced carbon cycle in surface fresh waters. J. Geophys. Res. 89: 4657-4676. doi:10.1029/JD089iD03p04657

Koné, Y. J. M., and A. V. Borges. 2008. Dissolved inorganic carbon dynamics in the waters surrounding forested mangroves of the Ca Mau Province (Vietnam). Estuar. Coast. Shelf Sci. 77: 409-421. doi:10.1016/j.ecss.2007.10.001

Koné, Y. J. M., G. Abril, K. N. Kouadio, B. Delille, and A. V. Borges. 2009. Seasonal variability of carbon dioxide in the rivers and lagoons of Ivory Coast (West Africa). Estuaries Coast. 32: 246-260. doi:10.1007/s12237-008-9121-0

Koné, Y. J. M., G. Abril, B. Delille, and A. V. Borges. 2010. Seasonal variability of methane in the rivers and lagoons of Ivory Coast (West Africa). Biogeochemistry 100: 21-37. doi:10.1007/s10533-009-9402-0

Laruelle, G. G., H. H. Dürr, C. P. Slomp, and A. V. Borges. 2010. Evaluation of sinks and sources of $\mathrm{CO}_{2}$ in the global coastal ocean using a spatially-explicit typology of estuaries and continental shelves. Geophys. Res. Lett. 37: L15607. doi:10.1029/2010GL043691

Levinton, J. S., and J. R. Waldman. 2006. The Hudson River Estuary: Executive summary, p. 1-10. In J. S. Levinton and J. R. Waldman [eds.], The Hudson River Estuary. Cambridge Univ. Press.

Liss, P. S., and P. G. Slater. 1974. Flux of gases across the airsea interface. Nature 247: 181-184. doi:10.1038/247181a0

Maher, D. T., K. Cowley, I. R. Santos, P. Macklin, and B. D. Eyre. 2015. Methane and carbon dioxide dynamics in a subtropical estuary over a diel cycle: Insights from automated in situ radioactive and stable isotope measurements. Mar. Chem. 168: 69-79. doi:10.1016/j.marchem2014.10.017

Marescaux, A., V. Thieu, and J. Garnier. 2018. Carbon dioxide, methane and nitrous oxide emissions from the humanimpacted Seine watershed in France. Sci. Total Environ. 643: 247-259. doi:10.1016/j.scitotenv.2018.06.151

Martinez-Cruz, K., R. Gonzalez-Valencia, A. SepulvedaJauregui, F. Plascencia-Hernandez, Y. Belmonte-Izquierdo, and F. Thalasso. 2017. Methane emission from aquatic ecosystems of Mexico City. Aquat. Sci. 79: 159-169. doi: 10.1007/s00027-016-0487-y

McAuliffe, C. D. 1971. Gas chromatographic determination of solutes by multiple phase equilibrium. Chem. Technol. 1: 46-51.
McCallister, S. L., J. E. Bauer, J. E. Cherrier, and H. W. Ducklow. 2004. Assessing sources and ages of organic matter supporting river and estuarine bacterial production: A multiple-isotope $\left(\Delta^{14} \mathrm{C}, \delta^{13} \mathrm{C}\right.$, and $\left.\delta^{15} \mathrm{~N}\right)$ approach. Limnol. Oceangr. 49: 1687-1702. doi:10.4319/lo.2004.49.5.1687

McClain, M. E., and others. 2003. Biogeochemical hot spots and hot moments at the interface of terrestrial and aquatic ecosystems. Ecosystems 6: 301-312. doi:10.1007/s10021-003-0161-9

McGinnis, D. F., and others. 2016. Deconstructing methane emissions from a small northern European river: Hydrodynamics and temperature as key drivers. Environ. Sci. Technol. 50: 11680-11687. doi:10.1021/acs.est.6b03268

Middelburg, J. J., and others. 2002. Methane distribution in European tidal estuaries. Biogeochemistry 59: 95-119. doi: 10.1023/A:1015515130419

Müller, D., and others. 2016a. Nitrous oxide and methane in two tropical estuaries in a peat-dominated region of northwestern Borneo. Biogeosciences 13: 2415-2428. doi: 10.5194/bg-13-2415-2016

Müller, D., and others. 2016b. Fate of terrestrial organic carbon and associated $\mathrm{CO}_{2}$ and $\mathrm{CO}$ emissions from two southeast Asian estuaries. Biogeosciences 13: 691-705. doi: 10.5194/bg-13-691-2016

Murray, R. H., D. V. Erler, and B. D. Eyre. 2015. Nitrous oxide fluxes in estuarine environments: Response to global change. Glob. Chang. Biol. 21: 3219-3245. doi:10.1111/gcb.12923

Nightingale, P. D., and others. 2000. In situ evaluation of airsea gas exchange parameterizations using novel conservative and volatile tracers. Global Biogeochem. Cycles 14: 373-387. doi:10.1029/1999GB900091

Nitsche, F. O., and others. 2007. Regional patterns and local variations of sediment distribution in the Hudson River Estuary. Estuar. Coast. Shelf Sci. 71: 259-277. doi:10.1016/ j.ecss.2006.07.021

Noriega, C. E. D., M. Araujo, and N. Lefevre. 2013. Spatial and temporal variability of the $\mathrm{CO}_{2}$ fluxes in a trpoical, high urbanized estuary. Estuaries Coast. 36: 1054-1072. doi: 10.1007/s12237-013-9608-1

NYCDEP. 2009-2011. Waterbody/watershed facility plan report: Vols. 1-9, year 2009-2011. In City-wide long term CSO control planning project. City of New York Department of Environmental Protection.

NYCDEP. 2004. New York Harbor Water Quality Report, year 2005. City of New York Department of Environmental Protection.

Rajkumar, A. N., J. Barnes, R. Ramesh, R. Purvaja, and R. C. Upstill-Goddard. 2008. Methane and nitrous oxide fluxes in the polluted Adyar River and Estuary, SE India. Mar. Pollut. Bull. 56: 2043-2051. doi:10.1016/j.marpolbul.2008.08.005

Raymond, P. A., N. F. Caraco, and J. J. Cole. 1997. Carbon dioxide concentration and atmospheric flux in the Hudson River. Estuaries 20: 381-390. doi:10.2307/1352351

Raymond, P. A., J. E. Bauer, and J. J. Cole. 2000. Atmospheric $\mathrm{CO}_{2}$ evasion, dissolved inorganic carbon production, and 
net heterotrophy in the York River estuary. Limnol. Oceanogr. 45: 1707-1717. doi:10.4319/lo.2000.45.8.1707

Raymond, P. A., and J. J. Cole. 2001. Gas exchange in rivers and estuaries: Choosing a gas transfer velocity. Estuaries 24: 312-317. doi:10.2307/1352954

Raymond, P. A., and others. 2012. Scaling the gas transfer velcoity and hydraulic gemotery in streams and small rivers. Limnol. Oceanogr.: Fluids Environ. 2: 41-53. doi: 10.1215/21573689-1597669

Regnier, P., and others. 2013. Modelling estuarine biogeochemical dynamics: From the local to the global scale. Aquat. Geochem. 19: 591-626. doi:10.1007/s10498-0139218-3

Sawakuchi, H. O., et al. 2017. Carbon dioxide emissions along the lower Amazon River. Front. Mar. Sci. 4. doi:10.3389/ farms.2017.00076

Schlesinger, W. H. 2009. On the fate of anthropogenic nitrogen. Proc. Natl. Acad. Sci. USA 106: 203-208. doi:10.1073/ pnas.0810193105

Shalini, A., R. Ramesh, R. Purvaja, and J. Barnes. 2006. Spatial and temporal distribution of methane in an extensive shallow estuary, South India. J. Earth Syst. Sci. 115: 451-460. doi:10.1007/BF02702873

Smith, R. M., S. S. Kaushal, J. J. Beaulieu, M. J. Pennino, and C. Welty. 2017. Influence of infrastructure on water quality and greenhouse gas dynamics in urban streams. Biogeosciences 14: 2831-2849. doi:10.5194/bg-14-2831-2017

Turner, R. E., and N. N. Rabalais. 1994. Coastal eutrophication near the Mississippi river delta. Nature 368: 619-621. doi: 10.1038/368619a0

Upstill-Goddard, R. C., J. Barnes, T. Frost, S. Punshon, and N. J. P. Owens. 2000. Methane in the southern North Sea: Low-salinity inputs, estuarine removal, and atmospheric flux. Global Biogeochem. Cycles 14: 1205-1217. doi: 10.1029/1999GB001236

Wang, Z. A., and W.-J. Cai. 2004. Carbon dioxide degassing and inorganic carbon export from a marsh-dominated estuary (the Duplin River): A marsh $\mathrm{CO}_{2}$ pump. Limnol. Oceanogr. 49: 341-354. doi:10.4319/lo.2004.49.2.0341

Wanninkhof, R. 1992. Relationship between wind speed and gas exchange over the ocean. J. Geophys. Res. Oceans 97: 7373-7382. doi:10.1029/92JC00188

Wanninkhof, R., and others. 1993. Gas transfer experiment on Georges Bank using two volatile deliberate tracers. J. Geophys. Res. Oceans 98: 20237-20248. doi:10.1029/ 93JC01844

Weatherburn, M. W. 1967. Phenol-hypochlorite reaction for determination of ammonia. Anal. Chem. 39: 971-974. doi: $10.1021 / \mathrm{ac} 60252 \mathrm{a} 045$
Weiss, R. F. 1974. Carbon dioxide in water and seawater: The solubility of a non-ideal gas. Mar. Chem. 2: 203-215. doi: 10.1016/0304-4203(74)90015-2

Young, S., A. Juhl, and G. D. Mullan. 2013. Antibiotic-resistant bacteria in the Hudson River Estuary linked to wet weather sewage contamination. J. Water Health 11: 297-310. doi: 10.2166/wh.2013.131

Zappa, C. J., P. A. Raymond, E. A. Terray, and W. R. McGillis. 2003. Variation in surface turbulence and the gas transfer velocity over a tidal cycle in a macro-tidal estuary. Estuaries 26: 1401-1415. doi:10.1007/BF02803649

Zappa, C. J., W. R. McGillis, P. A. Raymond, J. B. Edson, E. J. Hintsa, H. J. Zemmelink, J. W. H. Dacey, and D. T. Ho. 2007. Environmental turbulent mixing controls on air-water gas exchange in marine and aquatic systems. Geophys. Res. Lett. 34: L10601. doi:10.1029/2006GL028790

Zhai, W., M. Dai, and X. Guo. 2007. Carbonate system and $\mathrm{CO}_{2}$ degassing fluxes in the inner estuary of Changjiang (Yangtze) River, China. Mar. Chem. 107: 342-356. doi: 10.1016/j.marchem.2007.02.011

Zhang, G., J. Zhang, J. Ren, J. Li, and S. Liu. 2008. Distributions and sea-to-air fluxes of methane and nitrous oxide in the North East China Sea in summer. Mar. Chem. 110: 42-55. doi:10.1016/j.archem.2008.02.005

\section{Acknowledgments}

We thank WeatherFlow and F.O. Nitsche for providing access and use of meteorological and volume data in the Hudson River Valley, respectively. We also thank Riverkeeper, especially John Lipscomb, Captain of the Riverkeeper patrol boat, R. Ian Fletcher, for logistical and sampling support. Carol Knudson of Lamont Doherty Earth Observatory also helped with logistics and sampling. In addition, we thank Lindsey Macpherson for editing of the manuscript. Last, we thank the efforts of the editors of Limnology and Oceanography, as well as our anonymous reviewers whose contributions greatly strengthened this manuscript. This research was supported by the Hudson River Foundation Mark B. Bain Graduate Fellowship, "Evaluating greenhouse gas efflux across a rural-urban estuarine gradient: assessing the impact of incomplete wastewater treatment on the Hudson River" awarded to BAB. Biogeochemical sampling was supported by the Sloan Foundation CUNY JFRASE, Riverkeeper, and PSCCUNY awards to GDO and JAB.

\section{Conflict of Interest}

None declared.
Submitted 26 June 2018

Revised 27 October 2018

Accepted 25 April 2019

Associate editor: Bo Thamdrup 